\title{
A Monte Carlo Procedure for the Construction of Complementary Cumulative Distribution Functions for Comparison with the EPA Release Limits for Radioactive Waste Disposal
}

\author{
J. C. Helton and A.W. Shiver \\ WIPP Performance Assessment Computational Support Department \\ Sandia National Laboratories \\ Albuquerque, New Mexico 87185-1328
}

\begin{abstract}
A Monte Carlo procedure for the construction of complementary cumulative distribution functions (CCDFs) for comparison with the U.S. Environmental Protection Agency (EPA) release limits for radioactive waste disposal (40 CFR 191, Subpart B) is described and illustrated with results from a recent performance assessment (PA) for the Waste Isolation Pilot Plant (WIPP). The Monte Carlo procedure produces CCDF estimates similar to those obtained with stratified sampling in several recent PAs for the WIPP. The advantages of the Monte Carlo procedure over stratified sampling include increased resolution in the calculation of probabilities for complex scenarios involving drilling intrusions and better use of the necessarily limited number of mechanistic calculations that underlie CCDF construction.
\end{abstract}

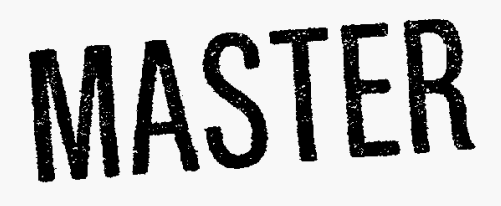




\section{ACKNOWLEDGMENT}

Review of this presentation was provided by M.G. Marietta and M.S. Tierney of Sandia National Laboratories and is gratefully acknowledged. Further, this presentation would not have been possible without the diligent and high-quality work of the many members of the 1991 and 1992 WIPP PA teams, including D.R. Anderson, B.L. Baker, J.E. Bean, J.W. Berglund, W. Beyeler, K. Economy, J.W. Garner, S.C. Hora, H.J. Iuzzolino, P. Knupp, M.G. Marietta, J. Rath, R.P. Rechard, P.J. Roache, D.K. Rudeen, K. Salari, J.D. Schreiber, P.N. Swift, M.S. Tierney, and P. Vaughn. Editorial support was provided by Tech Reps, Inc., with special thanks to H. Olmstead, J. Ripple, and D. Sessions. Work performed for Sandia National Laboratories and the U.S. Department of Energy under contract number DE-AC04-76DP00789. However, the views and ideas expressed in this presentation are the authors' and should not be interpreted as expressing any position or policy by the sponsors. 


\section{DISCLAIMER}

This report was prepared as an account of work sponsored by an agency of the United States Government. Neither the United States Government nor any agency thereof, nor any of their employees, make any warranty, express or implied, or assumes any legal liability or responsibility for the accuracy, completeness, or usefulness of any information, apparatus, product, or process disclosed, or represents that its use would not infringe privately owned rights. Reference herein to any specific commercial product, process, or service by trade name, trademark, manufacturer, or otherwise does not necessarily constitute or imply its endorsement, recommendation, or favoring by the United States Government or any agency thereof. The views and opinions of authors expressed herein do not necessarily state or reflect those of the United States Government or any agency thereof. 


\section{DISCLAIMER}

Portions of this document may be illegible in electronic image products. Images are produced from the best available original document. 


\section{CONTENTS}

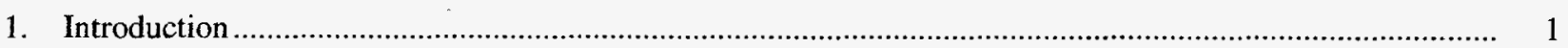

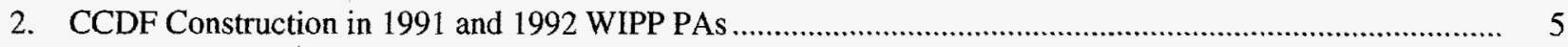

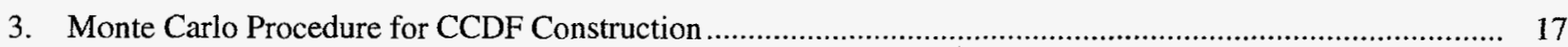

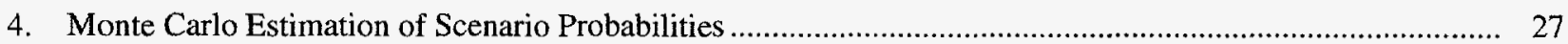

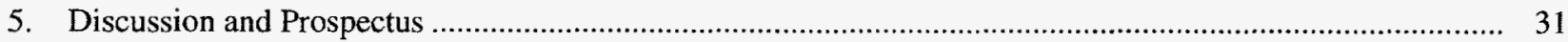

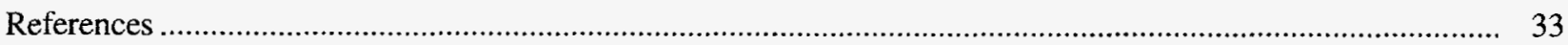




\section{Figures}

Figure

1 Comparison of CCDF for normalized release to the accessible environment with boundary line specified in 191.13(a).

2 Location of Waste Disposal Panels at the WIPP.

3 Construction of a CCDF from the Kaplan/Garrick ordered triple representation for risk

4 Computer programs used in 1991 WIPP PA.

5 Distribution of CCDFs for normalized release to the accessible environment due to cuttings removal

(left frame) and groundwater transport (right frame) obtained in the 1991 WIPP PA.

6 Estimated CCDFs for sample element 46.

7 Estimated CCDFs for sample element 46 obtained with importance sampling and a Monte Carlo sample of size $5 \times 10^{5}$.

8 Estimated CCDFs for sample element 46 obtained with Monte Carlo samples of size $5 \times 10^{2}, 5 \times 10^{3}$, $5 \times 10^{4}$ and $5 \times 10^{5}$.

\section{Tables}

Table

1 Release Limits for the Containment Requirements

2 Projected Activity Levels $\left(\mathrm{Ci} / \mathrm{m}^{2}\right)$ in Waste That Is Currently Stored and May Be Shipped to the WIPP

3 Normalized Radionuclide Releases Used to Illustrate Scenario Construction Procedures.

4 Assumptions Used in Construction of Groundwater Release to the Accessible Environment $n R G(x)$ for an Arbitrary Element $x$ of $S_{s t}$

5 Parameter Values Used in Example Calculation of Probabilities for E1E2-Type Scenarios

6 Comparison of Probabilities for Scenarios Involving E1E2-Type Intrusions That Occur with Fixed Time Intervals for the Defining Boreholes.

7 Comparison of Probabilities for Scenarios Involving E1E2-Type Intrusions That Occur with Fixed Separation Times for the Defining Boreholes.... 


\section{Introduction}

The U.S. Environmental Protection Agency (EPA) has promulgated the following containment requirement for the geologic disposal of radioactive waste:1,2

$\S 191.13$ Containment requirements.

(a) Disposal systems for spent nuclear fuel or high-level or transuranic radioactive wastes shall be designed to provide a reasonable expectation, based upon performance assessments, that cumulative releases of radionuclides to the accessible environment for 10,000 years after disposal from all significant processes and events that may affect the disposal system shall:

(1) Have a likelihood of less than one chance in 10 of exceeding the quantities calculated according to Table 1 (Appendix A); and

(2) Have a likelihood of less than one chance in 1,000 of exceeding ten times the quantities calculated according to Table 1 (Appendix A).

(b) Performance assessments need not provide complete assurance that the requirements of 191.13(a) will be met. Because of the long time period involved and the nature of the events and processes of interest, there will inevitably be substantial uncertainties in projecting disposal system performance. Proof of the future performance of a disposal system is not to be had in the ordinary sense of the word in situations that deal with much shorter time frames. Instead, what is required is a reasonable expectation, on the basis of the record before the implementing agency, that compliance with 191.13(a) will be achieved.

Further, "accessible environment" means (a) the atmosphere, (b) land surfaces, (c) surface waters, (d) oceans, and (e) all of the lithosphere that is beyond the controlled area, and "controlled area" means (a) a surface location, to be identified by passive institutional controls, that encompasses no more than $100 \mathrm{~km}^{2}$ and extends horizontally no more than $5 \mathrm{~km}$ in any direction from the outer boundary of the original location of the radioactive wastes in a disposal system, and (b) the subsurface underlying such a surface location. Table 1 (Appendix A) referred to in the preceding quote is reproduced here as Table 1.

Associated with Table 1 (App. A) of Ref. 1 are instructions for converting a radionuclide release to the accessible environment over $10,000 \mathrm{yr}$ (units: $\mathrm{Ci}$ ) to a normalized release (units: dimensionless) for different types of radioactive waste. For transuranic waste, which is the waste category considered in this presentation, the normalized release $n R$ is defined by

$$
n R=\sum_{i}\left(\frac{Q_{i}}{L_{i}}\right)\left(1 \times 10^{6} \mathrm{Ci} / C\right)
$$


Table 1. Release Limits for the Containment Requirements (Ref. 1, App. A, Table 1)

\begin{tabular}{lc}
\hline \multicolumn{1}{c}{ Radionuclide } & $\begin{array}{c}\text { Release Limit } \mathrm{L}_{i} \text { per } 1000 \mathrm{MTHM}^{\mathrm{a}} \text { or } \\
\text { other unit of waste }\end{array}$ \\
\hline Americum & 100 \\
Carbon 14 & 100 \\
Cesium-135 or -137 & 1,000 \\
Iodine-129 & 100 \\
Neptunium-237 & 100 \\
Plutonium-238, $-239,-240$, or -242 & 100 \\
Radium-226 & 100 \\
Strontium-90 & 1,000 \\
Technetium-99 & 10,000 \\
Thorium-230 or -232 & 10 \\
Tin-126 & 1,000 \\
Uranium-233, $-234,-235,-236$, or -238 & 100 \\
& 100 \\
Any other alpha-emitting radionuclide with & \\
a half-life greater than 20 years & 1,000 \\
Any other radionuclide with a half-life greater \\
than 20 years that does not emit alpha particles
\end{tabular}

where

$Q_{i}=$ cumulative release of radionuclide $i$ to the accessible environment during the 10,000-yr period following closure of the repository $(\mathrm{Ci})$,

$L_{i}=$ release limit for radionuclide $i$ given in Table $1(\mathrm{Ci})$,

$C=$ amount of transuranic waste emplaced in the repository (Ci).

The preceding normalization provides a way to reduce the effects of releases involving a variety of radionuclides to a single number.

Assessing compliance with 191.13 presents an interesting conceptual and computational problem due to the involvement of two different types of uncertainty. Requirement 191.13(a) specifies that the complementary cumulative distribution function (CCDF) for normalized radionuclide release to the accessible environment shall fall below a boundary line defined by the points $(1,0.1)$ and $(10,0.001)$ as indicated in Fig. 1. As such, 191.13(a) is an 


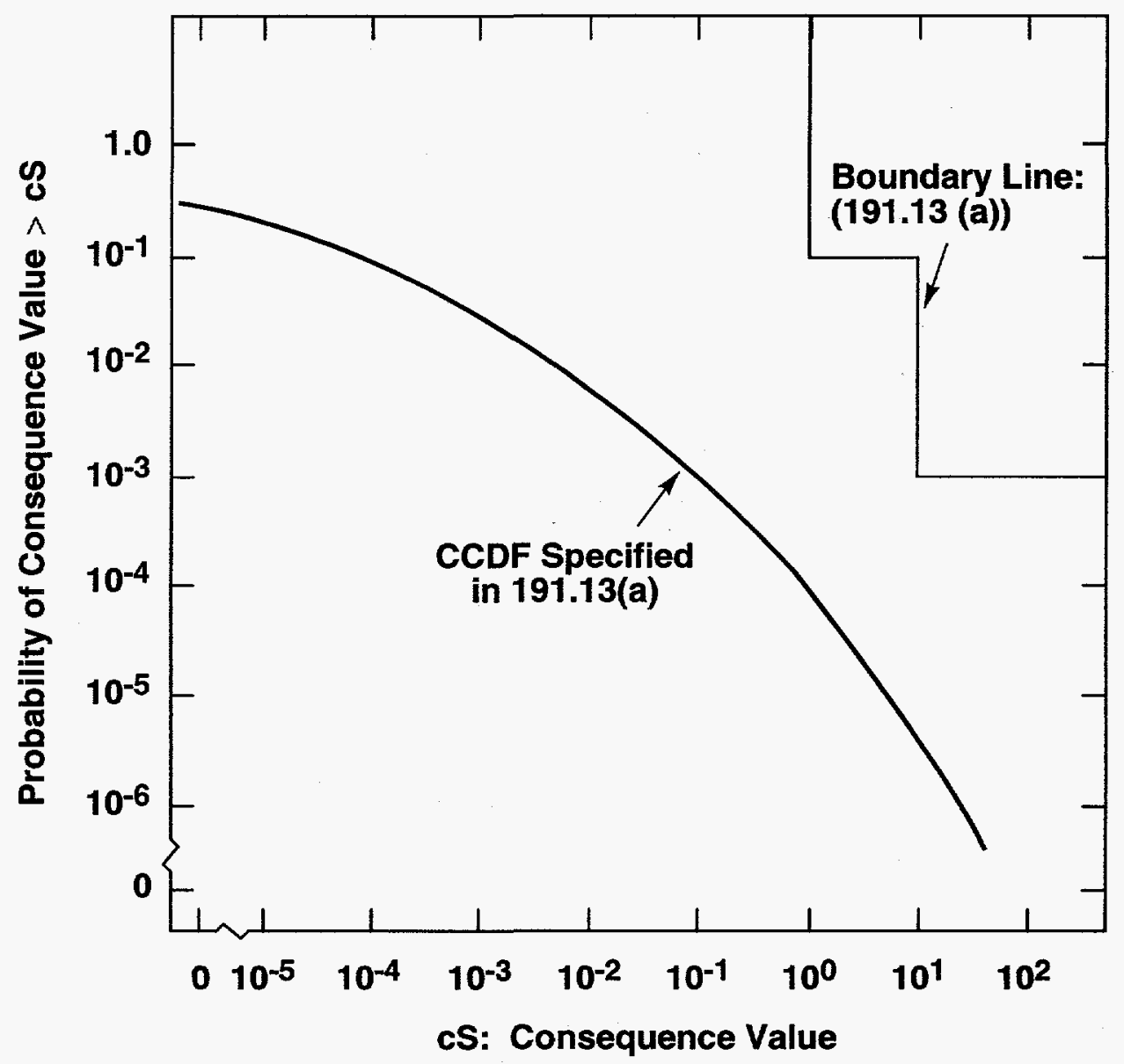

TRI-6342-730-10

Fig. 1. Comparison of CCDF for normalized release to the accessible environment with boundary line specified in 191.13(a).

example of the Farmer limit line approach to the definition of acceptable risk..$^{3-5}$ The uncertainty characterized by the CCDF associated with 191.13(a) arises because a waste disposal site could experience a variety of different disruptions and is often referred to as stochastic uncertainty. Requirement 191.13(b) specifies that performance assessments should provide "a reasonable expectation" that compliance with 191.13(a) will be achieved. The "reasonable expectation" associated with 191.13(b) arises from an assessment of how much uncertainty there is with respect to where the CCDF in 191.13(a) is actually located. The uncertainty addressed in 191.13(b) arises from a lack of knowledge on the part of the analysts attempting to assess compliance with 191.13(a) and is often referred to as subjective uncertainty. The importance of separating the effects of stochastic and subjective uncertainty, as specified in 191.13 , has been emphasized by a number of authors. ${ }^{6-16}$ 
The characterization of stochastic and subjective uncertainty involves the use of probability. Three entities are involved in a formal definition of probability: (1) a set $S$ that contains everything that could occur for the particular "universe" under construction, (2) a suitably restricted set $\mathcal{\&}$ of subsets of $\mathcal{S}$, called a Borel or $\sigma$-algebra, and (3) a function $p$ defined for elements of $\&$ that actually defines probability. ${ }^{17-19}$ Collectively, the triple $(\mathcal{S}, \&, p)$ is a called a probability space. In the terminology of probability theory, $S$ is the sample space, the elements of $S$ are elementary events, and the subsets of $S$ contained in $\&$ are events. The probability space $\left(S_{s t}, \&_{s t}, p_{s t}\right)$ associated with stochastic uncertainty gives rise to the CCDF specified in $191.13(\mathrm{a})$, and the probability space $\left(S_{s u}, \&_{s u}, p_{s u}\right)$ associated with subjective uncertainty determines whether or not there is a "reasonable expectation" that 191.13(a) will be met as required by 191.13 (b). In practice, a full measure-theoretic development of probability ${ }^{17-19}$ is never performed in a PA for a complex system. However, it is useful to introduce the idea of a probability space to emphasize that two internally-consistent developments of probability underly the treatment of stochastic and subjective uncertainty.

Preliminary performance assessments (PAs) conducted for the Waste Isolation Pilot Plant (WIPP) in 199120-23 and $1992^{24-28}$ have used an experimental design based on importance sampling (Ref. 29, Sect. 5.4) to investigate the probability space for stochastic uncertainty and construct the CCDF specified in 191.13(a) and a random design based on Latin hypercube sampling ${ }^{30,31}$ to investigate the probability space for subjective uncertainty and assess the "reasonable expectation" called for in 191.13(b). This presentation will describe a Monte Carlo procedure that can be used to investigate stochastic uncertainty in PAs for the WIPP instead of the previously used importance sampling procedure. Desirable features of this Monte Carlo procedure include conceptual simplicity, computational efficiency, increased resolution on scenario probability, and better estimates of normalized releases to the accessible environment.

The presentation is organized as follows. The procedures used in the 1991 and 1992 WIPP PAs to treat stochastic and subjective uncertainty are described in Sect. 2. This description also introduces much of the notation and the mechanistic calculations that are needed to describe and illustrate the Monte Carlo procedure. The Monte Carlo construction of CCDFs is then presented in Sect. 3 and results of such constructions are compared with results obtained in the 1991 WIPP PA. The use of Monte Carlo procedures to estimate probabilities for certain complex scenarios involving pressurized brine pockets (i.e., E1E2-scenarios in a commonly-used WIPP terminology) is discussed in Sect. 4. Finally, a concluding discussion and prospectus on possible uses of Monte Carlo procedures for CCDF construction are given in Sect. 5. 


\section{CCDF Construction in 1991 and 1992 WIPP PAs}

In the 1991 and 1992 WIPP PAs, the probability space $\left(\delta_{s t}, \delta_{s t}, p_{s t}\right)$ for stochastic uncertainty is defined by the following assumptions: (1) exploratory drilling for natural resources constitutes the only disruption at the WIPP with sufficient likelihood to be retained in the analysis (Ref. 21, Chapt. 3), (2) drilling intrusions follow a Poisson process $^{32-35}$ with a rate term $\lambda$, (3) waste is partitioned into five activity levels $\left(\mathrm{Ci} / \mathrm{m}^{2}\right)$ with a probability of $p L_{i}$ that a randomly placed borehole will intersect waste of activity level $i$ (Ref. 22, Table 3.4-11), and (4) a fraction $f P B_{l}$ of waste panel $l$ (Fig. 2) is underlain by pressurized brine (Ref. 22, Sect. 5.1.1). In this development, the sample space $S_{s t}$ is

$\mathcal{S}_{s t}=\{x: x$ a single 10,000 yr history beginning at the decommissioning of the WIPP $\}$.

Further, the set $\&_{s t}$ and function $p_{s t}$ were never fully developed. Rather, as described below and in more detail elsewhere, ${ }^{36}$ an importance sampling procedure was used to subdivide $S_{s t}$, with only those elements of $\delta_{s t}$ used in this importance sampling procedure being defined and assigned probabilities.

The importance sampling procedure used in the 1991 and 1992 WIPP PAs to subdivide $S_{s t}$ is based on the division of the 10,000-yr time period specified in 191.13(a) into a sequence

$$
\left[t_{i-1}, t_{i}\right], i=1,2, \ldots, n T \text {, }
$$

of disjoint time intervals. When the activity levels of the waste are not considered, these time intervals lead to subsets of $S_{s t}$ defined by

$$
S(n)=\left\{x: x \text { an element of } S_{s t} \text { for which exactly } n(i) \text { intrusions occur in time interval }\left[t_{i-1}, t_{i}\right] \text { for } i=1,2, \ldots, n T\right\}
$$

and

$$
\begin{aligned}
& \mathcal{S}^{+-}\left(t_{i-1}, t_{i}\right)=\left\{x: x \text { an element of } \mathcal{S}_{s t}\right. \text { for which two or more boreholes penetrate the same waste panel during } \\
& \text { the time interval }\left[t_{i-1}, t_{i}\right] \text {, with at least one of these boreholes penetrating a pressurized brine } \\
& \text { pocket }(+) \text { and at least one not penetrating a pressurized brine pocket }(-)\}
\end{aligned}
$$

where

$$
\mathbf{n}=[n(1), n(2), \ldots, n(n T)]
$$

In the 1991 WIPP PA, $n T=5$ and each time interval $\left[t_{i-1}, t_{i}\right]$ had a length of 2000 yrs. In the 1992 WIPP PA, the intervals $\left[t_{i-1}, t_{i}\right]$ were defined in two different ways. To represent releases due to cuttings removal, $n T=6$ and the individual intervals are $[0,150 \mathrm{yr}],[150,200 \mathrm{yr}],[200,500 \mathrm{yr}],[500,1500 \mathrm{yr}],[1500,4500 \mathrm{yr}]$ and $[4500$, 


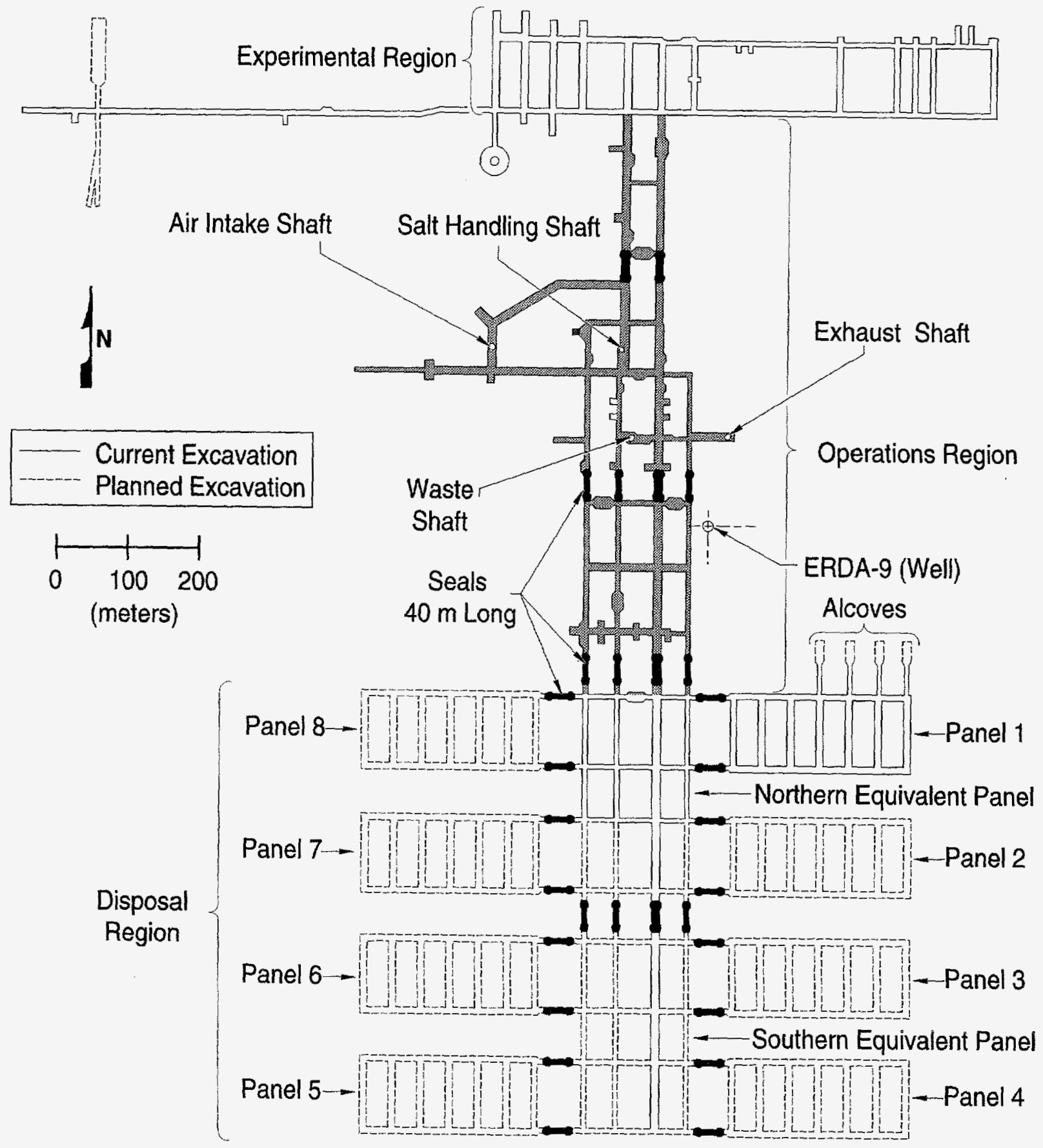

TRi- 6334-206-7

Fig. 2. Location of Waste Disposal Panels at the WIPP. 
$10,000 \mathrm{yr}]$; to represent releases due to groundwater transport, $n T=2$ and the individual time intervals are $[0,2000$ $\mathrm{yr}]$ and $[2000,10,000 \mathrm{yr}]$.

When the activity levels of the waste are considered for the calculation of cuttings removal, the preceding time intervals lead to scenarios defined by

$$
\begin{array}{r}
S(I, \mathbf{n})=\left\{x: x \text { an element of } S(\mathbf{n}) \text { for which the } j^{\text {th }} \text { borehole encounters waste of activity level } l(j) \text { for } j=1,2, \ldots,\right. \\
n B H, \text { where } n B H \text { is the total number of boreholes associated with a time history in } S(I, \mathbf{n})\}
\end{array}
$$

and

$$
\begin{aligned}
\mathcal{S}^{+-}\left(\mathbf{l} ; t_{i-1}, t_{i}\right)=\{x: & x \text { an element of } \mathcal{S}^{+-}\left(t_{i-1}, t_{i}\right) \text { for which the } j^{\text {th }} \text { borehole encounters waste of activity level } \\
& l(j) \text { for } j=1,2, \ldots, n B H \text {, where } n B H \text { is the total number of boreholes associated with a time } \\
& \text { history in } \left.\mathcal{S}^{+-}\left(\mathbf{1} ; t_{i-1}, t_{i}\right)\right\},
\end{aligned}
$$

where

$$
\mathbf{I}=[l(1), l(2), \ldots, l(n B H)] \text { and } n B H=\sum_{i=1}^{n T} n(i)
$$

The sets $S(\mathbf{I}, \mathbf{n})$ and $S^{+-}\left(\mathbf{l} ; t_{i-1}, t_{i}\right)$ were used as the strata (i.e., subsets of $\left.S_{s t}\right)$ in the importance sampling procedure used to incorporate stochastic uncertainty into the 1991 and 1992 WIPP PAs. The preceding sets are referred to as scenarios in most of the published literature relating to the 1991 and 1992 WIPP PAs (e.g., Refs. 27, 35-38); however, they will usually be referred to as strata in this presentation to emphasize that the procedures in use are a form of importance sampling.

The probabilities $p S(\mathbf{n})$ and $p S(\mathbf{l}, \mathbf{n})$ for $S(\mathbf{n})$ and $S(\mathbf{l}, \mathbf{n})$ are given by

$$
p S(\mathbf{I}, \mathbf{n})=\left\{\prod_{j=1}^{n B H}\left[\frac{\lambda^{n(i)}\left(t_{i}-t_{i-1}\right)^{n(i)}}{n(i) !}\right]\right\} \exp \left[-\lambda\left(t_{n T}-t_{0}\right)\right]
$$

and

$$
p S(\mathbf{I}, \mathbf{n})=\left(\prod_{j=1}^{n B H} p L_{l(j)}\right) p S(\mathbf{n})
$$

under the assumption that the occurrence of boreholes through the repository follows a Poisson process with a rate constant $\lambda$ (Ref. 21, Chapt. 2; Ref. 35), where $\mathbf{n}$ and $\mathbf{I}$ are defined in Eqs. (6) and (9), respectively, and $p L_{l}$ is the probability that a randomly placed borehole through a waste panel will encounter waste of activity level $l$.

The probabilities $p S^{+-}\left(t_{i-1}, t_{i}\right)$ and $p S^{+-}\left(\mathbf{1} ; t_{i-1}, t_{i}\right)$ for $\mathcal{S}^{+-}\left(t_{i-1}, t_{i}\right)$ and $\mathcal{S}^{+-}\left(\mathbf{l} ; t_{i-1}, t_{i}\right)$ are given by 


$$
p S^{+-}\left(t_{i-1}, t_{i}\right) \doteq \sum_{l=1}^{n P}\left\{1-\exp \left[-\alpha_{l}\left(t_{i}-t_{i-1}\right)\right]\right\}\left\{1-\exp \left[-\beta_{l}\left(t_{i}-t_{i-1}\right)\right]\right\}
$$

and

$$
p S^{+-}\left(\mathbf{1} ; t_{i-1}, t_{i}\right) \doteq\left(\prod_{j=1}^{n B H} p L_{l(j)}\right) p S^{+-}\left(t_{i-1}, t_{i}\right)
$$

where

$$
\begin{aligned}
\alpha_{l} & =a B P_{l} \lambda / a T O T \\
\beta_{l} & =\left(a T O T_{l}-a B P_{l}\right) \lambda / a T O T \\
a B P_{l} & =\text { area }\left(\mathrm{m}^{2}\right) \text { of pressurized brine pocket under waste panel } l, \\
a T O T_{l} & =\text { area }\left(\mathrm{m}^{2}\right) \text { of waste panel } l \\
a T O T & =\text { area }\left(\mathrm{m}^{2}\right) \text { of all waste panels, } \\
n P & =\text { number of waste panels. }
\end{aligned}
$$

As illustrated in Fig. 2, the current design for the WIPP involves $n P=10$ waste panels. For the 1991 and 1992 WIPP PAs, $a T O T_{l}$ and $a B P_{l}$ were assumed to be the same for all waste panels. Thus,

$$
a T O T_{l}=a T O T / n P \text { and } a B P_{l}=f B P \text { aTOT },
$$

where

$$
f B P=\sum_{l=1}^{n P} a B P_{l} / a T O T
$$

The expressions in Eqs. (11) and (12) are approximations, rather than exact formulas, for the probabilities $p S^{+-}\left(t_{i-1}\right.$, $t_{i}$ ) and $p S^{+-}\left(\mathbf{l} ; t_{i-1}, t_{i}\right)$ (Ref. 21, Chapt. 2; Ref. 35). As will be discussed later, one of the reasons for using a Monte Carlo procedure for $\mathrm{CCDF}$ construction is to obtain better approximations to these probabilities.

The probabilities $p S(\mathbf{I}, \mathbf{n})$ and $p S^{+-}\left(\mathbf{l} ; t_{i-1}, t_{i}\right)$ were used as the strata probabilities in the importance sampling procedure used in the 1991 and 1992 WIPP PAs. 
The 1991 and 1992 WIPP PAs used the Kaplan/Garrick ordered triple representation for risk ${ }^{7}$ to express the connection between the importance sampling procedure in use and the CCDF required in 191.13(a). In this representation, risk is defined to be a set $R$ of the form

$$
R=\left\{\left(S_{i}, p S_{i}, \mathbf{c S _ { i }}\right), i=1, \ldots, n S\right\},
$$

where

$$
\begin{aligned}
\mathcal{S}_{i} & =\text { a set of similar occurrences, } \\
p S_{i} & =\text { probability that an occurrence in the set } S_{i} \text { will take place, } \\
\mathbf{c S}_{i} & =\text { a vector of consequences associated with } S_{i} \\
n S & =\text { number of sets selected for consideration. }
\end{aligned}
$$

Further, the sets $S_{i}$ have no occurrences in common and $S_{s t}=\cup_{i} S_{i}$. In the context of the importance sampling procedure used in the 1991 and 1992 WIPP PAs, the $S_{i}$ are the strata associated with the design (i.e., $\mathcal{S}(I, n)$ and $\left.\mathcal{S}^{+-}\left(\mathbf{l} ; t_{i-1}, t_{i}\right)\right)$, and the $p S_{i}$ are the strata probabilities (i.e., $p S(\mathbf{l}, \mathbf{n})$ and $p S^{+-}\left(\mathbf{l} ; t_{i-1}, t_{i}\right)$ ). The vector $\mathbf{c S}_{i}$ contains environmental releases for individual isotopes, the normalized EPA release summed over all isotopes (Eq. (1)), and possibly other information associated with $\mathcal{S}_{i}$. As indicated in Fig. 3, each consequence $c S$ contained in cS leads to a CCDF. When $c S$ is the normalized EPA release summed over all isotopes, the CCDF required in 191.13(a) is obtained.

In the 1991 WIPP PA, the consequence vectors CS $_{i}$ in Eq. (16) were determined in a sequence of calculations involving the computer programs CUTTINGS (Ref. 21, Chapt. 7; Ref. 39), BRAGFLO (Ref. 21, Chapt. 5), PANEL (Ref. 21, Chapt. 5), SECO2D (Ref. 21, Chapt. 6; Ref. 40) and STAFF2D (Ref. 21, Chapt. 6; Ref. 41) as indicated in Fig. 4. An overview of the mathematical models incorporated into these programs and used in the 1991 WIPP PA is presented in Sect. 3 of Helton et al. ${ }^{38}$ The same sequence of models was also used in the 1992 WIPP PA with the exception that the SECO-TRANSPORT model (Ref. 25, Chapt. 7, App. C) was used instead of the STAFF2D to represent radionuclide transport in the Culebra Dolomite.

The importance sampling procedure used in the 1991 and 1992 WIPP PAs leads to too many strata to perform a detailed calculation for each strata with the models in Fig. 4. Rather, it is necessary to perform detailed release calculations for a relatively small number of strata and then to use these calculations to construct the releases associated with the remaining strata. In particular, the following results can be calculated for the time intervals $\left[t_{i-1}\right.$, $\left.t_{i}\right], i=1, \ldots, n T$, in Eq. (3): 


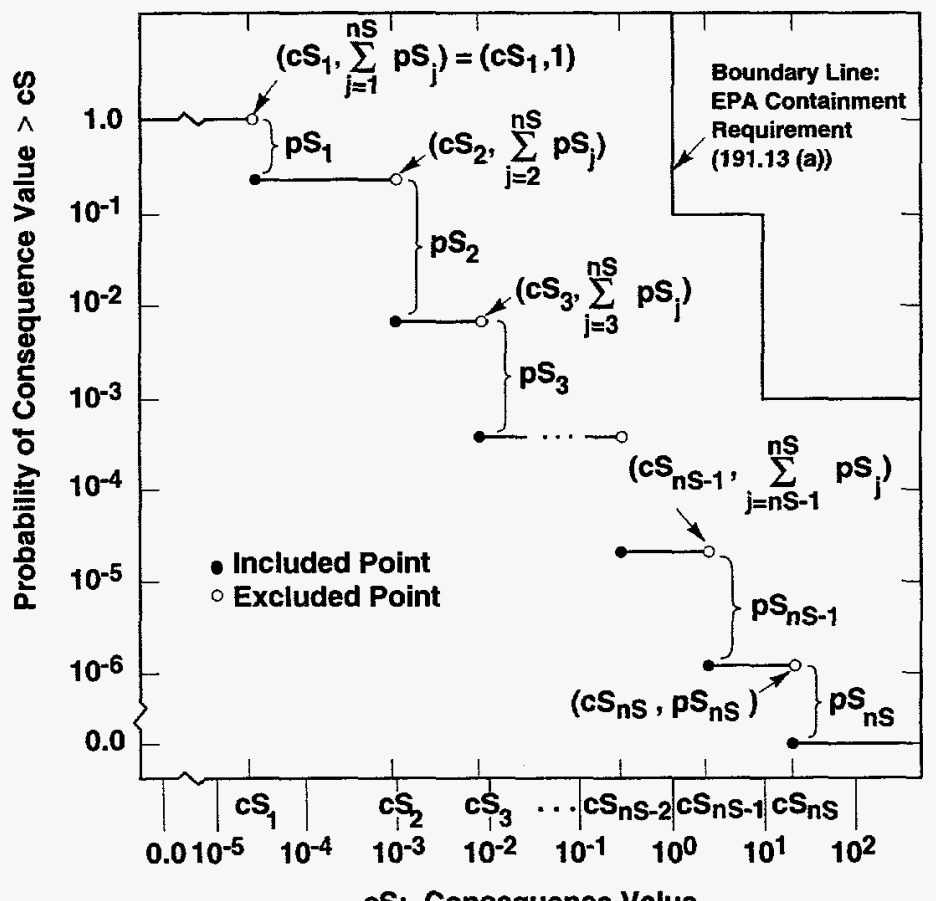

TAI-6342-730-8

Fig. 3. Construction of a CCDF from the Kaplan/Garrick Ordered Triple Representation for Risk. The $S_{i}$ are assumed to be ordered so that $c S_{i} \leq c S_{i+1}, i=1,2, \ldots, n S-1$, for the particular consequence $c S$ under consideration.

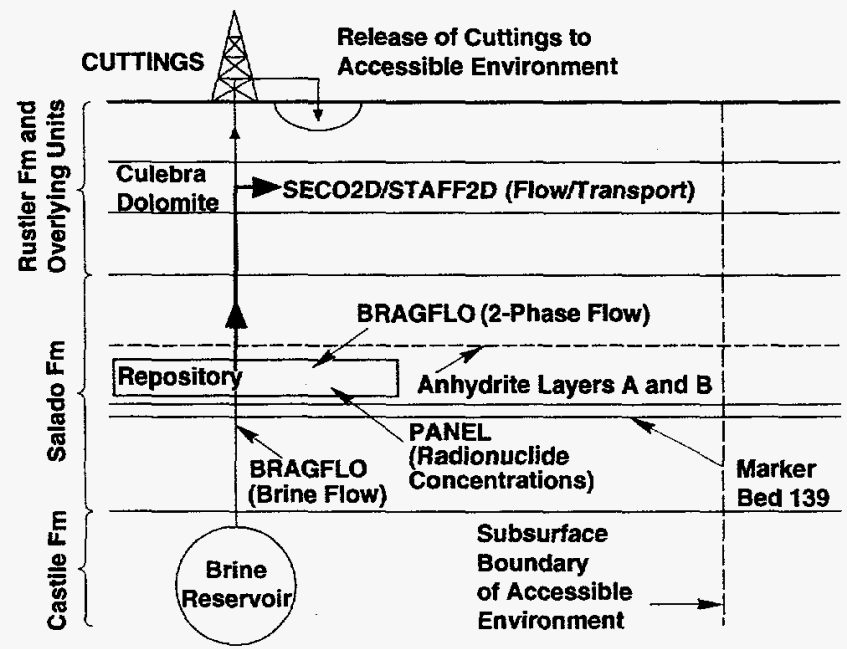

Not to Scale

TA1-6342-93-11

Fig. 4. Computer programs used in 1991 WIPP PA. 
$r C_{i}=$ EPA normalized release to the surface environment for cuttings removal due to a single borehole in time interval $i$ with the assumption that the waste is homogeneous (i.e., wastes of different activity levels are not present),

$r C_{i l}=$ EPA normalized release to the surface environment for cuttings removal due to a single borehole in time interval $i$ that penetrates waste of activity level $l$,

$r G W I_{i}=$ EPA normalized release to the accessible environment due to groundwater transport initiated by a single borehole in time interval $i$ (i.e., an E2-type scenario),

$r G W 2_{i}=$ EPA normalized release to the accessible environment due to groundwater transport initiated by two boreholes in the same waste panel in time interval $i$, of which one penetrates a pressurized brine pocket and one does not (i.e., an E1E2-type scenario),

with the assumption that the intrusions occur at the midpoints of the time intervals (e.g., at 1000, 3000, 5000, 7000 and 9000 yrs in the 1991 WIPP PA).

The normalized releases $r C_{i}, r C_{i l}$ and $r G W I_{i}$ can be used to construct the EPA normalized releases for $S(\mathbf{n})$ and $S(I, \mathbf{n})$. For $S(\mathbf{n})$, the normalized release to the accessible environment $c S(\mathbf{n})$ is given by

$$
c S(\mathbf{n})=\sum_{j=1}^{n B H}\left(r C_{m(j)}+r G W l_{m(j)}\right)
$$

where $m(j)$ designates the time interval in which the $j^{\text {th }}$ borehole occurs. The vector

$$
\mathbf{m}=[m(1), m(2), \ldots, m(n B H)]
$$

is uniquely determined once the vector $\mathbf{n}$ appearing in the definition of $\mathcal{S}(\mathbf{n})$ is specified. Further, the normalized release to the accessible environment $c S(\mathbf{I}, \mathbf{n})$ for $S(I, \mathbf{n})$ is given by

$$
c S(\mathbf{I}, \mathbf{n})=\sum_{j=1}^{n B H}\left(r C_{m(j), l(j)}+r G W l_{m(j)}\right)
$$

Similarly, the normalized releases to the accessible environment $c S^{+-}\left(t_{i-1}, t_{i}\right)$ and $c S^{+-}\left(\mathbf{l} ; t_{i-1}, t_{i}\right)$ for $S^{+-}\left(t_{i-1}, t_{i}\right)$ and $\mathcal{S}^{+-}\left(\mathbf{l} ; t_{i-1}, t_{i}\right)$ can be approximated by

$$
c S^{+-}\left(t_{i-1}, t_{i}\right)=2 r C_{i}+r G W 2_{i}
$$

and

$$
c S^{+-}\left(\mathrm{l} ; t_{i-1}, t_{i}\right)=\sum_{j=1}^{2} r C_{i, l(j)}+r G W 2_{i}
$$


respectively. Once the $c S(\mathbf{I}, \mathbf{n})$ and $c S^{+-}\left(\mathbf{l} ; t_{i-1}, t_{i}\right)$ are determined, the CCDF for comparison with the EPA release limits can be constructed as indicated in Fig. 3.

So far, this section has outlined the importance sampling procedure used to incorporate stochastic uncertainty into the 1991 and 1992 WIPP PAs. Subjective uncertainty enters the analysis when parameter values must be selected and various other decisions made in the quantification of the risk representation $R$ in Eq. (16). Specifically, $R$ can be viewed as a function of the form

$$
R(\mathbf{x})=\left\{\left[S_{i}(\mathbf{x}), p S_{i}(\mathbf{x}), c S_{i}(\mathbf{x})\right], i=1, \ldots, n S(\mathbf{x})\right\}
$$

where

$$
\mathbf{x}=\left[x_{1}, x_{2}, \ldots, x_{n I}\right]
$$

is a vector of inputs required in the determination of $R$ and thus in the determination of the CCDF specified in 191.13(a). Lack of knowledge about the appropriate value to use for $\mathbf{X}$ is subjective uncertainty and is characterized by the probability space $\left(S_{s u}, \delta_{s u}, p_{s u}\right)$ for subjective uncertainty.

In the 1991 and 1992 WIPP PAs, the probability space $\left(S_{s u}, \delta_{s u}, p_{s u}\right)$ for subjective uncertainty was defined by specifying distributions

$$
D_{1}, D_{2}, \ldots, D_{n I}
$$

for the elements of $\mathbf{x}$, where $D_{j}$ is the distribution for $x_{j}$. These distributions characterize subjective uncertainty and indicate a degree of belief as to where the appropriate value to use for each variable is located. Specifically, the sample space $S_{s u}$ for subjective uncertainty consists of all possible values for $\mathbf{x}$, and the definitions of $b_{s u}$ and $p_{s u}$ follow from the $D_{j}$. The 1991 WIPP PA considered $n l=45$ imprecisely-known variables (Ref. 22, Tables 6.0-1, 6.02, 6.0-3; also, Ref. 37, Table VIII and Ref. 38, Table 8). The variables contained in $\mathbf{x}$ for the 1992 WIPP PA were modified slightly, with a total of $n I=49$ variables contained in $\mathbf{x}$ (Ref. 26, Tables 6.0-1, 6.0-2, 6.0-3; Ref. 27, Table 3-1). As some of the variables contained in $\mathbf{X}$ affect the definition of the probability space for stochastic uncertainty (e.g., the rate constant $\lambda$ in the Poisson model for drilling intrusions), this space is actually a function $\left[S_{s t}(\mathbf{x}), \mathscr{\delta}_{s t}(\mathbf{x})\right.$, $\left.p_{s t}(\mathbf{x})\right]$ of $\mathbf{x}$.

The 1991 and 1992 WIPP PAs used a random design to incorporate the probability space for subjective uncertainty into the analysis to show compliance with 191.13 and, in particular, to satisfy the "reasonable expectation" requirement in 191.13(b). Specifically, Latin hypercube sampling ${ }^{30,31}$ was used to generate a sample

$$
\mathbf{x}_{k}, k=1,2, \ldots, n K,
$$


from the $\mathbf{x}$ (i.e., from $\mathcal{S}_{s u}$ ) according to the distributions indicated in Eq. (28). Further, the Iman/Conover restricted pairing technique ${ }^{42}$ was used to induce specified correlations between correlated variables and to assure that uncorrelated variables had correlations close to zero. Sample sizes of $n K=60$ and $n K=70$ were used in the 1991 and 1992 WIPP PAs, respectively.

A random design, and Latin hypercube sampling in particular, was selected as the experimental design for subjective uncertainty for several reasons (Ref. 43, Sect. 2.6): (1) efficient stratification across the full range of each variable, (2) ease of incorporation of correlations, (3) computational efficiency, (4) ease of implementation, (5) conceptual simplicity, (6) facilitation of sensitivity analysis, and (7) observed robustness in past studies (Refs. 4446). In contrast, the high dimensionality of $\mathcal{S}_{s u}$ (i.e., $S_{s u}$ is a subset of $R^{45}$ and $R^{49}$ in the 1991 and 1992 WIPP PAs, respectively) and associated correlation structure make importance sampling and classical experimental designs (e.g., fractional factorial, central composite, ...) unlikely candidates for the incorporation of subjective uncertainty.

Evaluation of $R$ for the sample elements $\mathbf{x}_{k}$ in Eq. (20) leads to the sequence of results

$$
R\left(\mathbf{x}_{k}\right)=\left\{\left[S_{i}\left(\mathbf{x}_{k}\right), p S_{i}\left(\mathbf{x}_{k}\right), \mathbf{c S}_{i}\left(\mathbf{x}_{k}\right)\right], i=1, \ldots, n S\left(\mathbf{x}_{k}\right)\right\}
$$

for $k=1, \ldots, n K$. For a given set $R\left(\mathbf{x}_{k}\right)$, each consequence result $c S$ contained in the vectors $\mathbf{c S}_{i}\left(\mathbf{x}_{k}\right)$ leads to a CCDF as shown in Fig. 3 that displays the effect of stochastic uncertainty (i.e., this CCDF derives from the probability space $\left(\mathcal{S}_{s t}, \&_{s t}, p_{s t}\right)$ or, more explicitly, the probability space $\left.\left[S_{s t}\left(\mathbf{x}_{k}\right), \&_{s t}\left(\mathbf{x}_{k}\right), p_{s t}\left(\mathbf{x}_{k}\right)\right]\right)$. In turn, consideration of all the $R\left(\mathbf{x}_{k}\right)$ leads to a distribution of CCDFs for each consequence result that displays the effect of subjective uncertainty (i.e., this distribution of CCDFs derives from the probability space $\left(S_{s u}, \&_{s u}, p_{s u}\right)$ for subjective uncertainty). As an example, the distributions of CCDFs for normalized release to the accessible environment due to cuttings removal and groundwater transport obtained in the 1991 WIPP PA are shown in Fig. 5. The individual CCDFs in this figure result from stochastic uncertainty, while the distributions of CCDFs result from subjective uncertainty. It is the location of the distribution of CCDFs in Fig. 5 relative to the limit line specified in 191.13(a) that is providing information on the "reasonable expectation" required in 191.13(b) that 191.13(a) will be met. In particular, the appearance of all or most of the CCDFs in distributions of the form shown in Fig. 5 is indicative of a "reasonable expectation" that 191.13(a) will be met.

Results obtained in the analysis that lead to the CCDFs in Fig. 5 will be used to illustrate the Monte Carlo procedure for $\mathrm{CCDF}$ construction presented in the next section. In particular, results obtained for sample element 46 in the 1991 WIPP PA will be used as this sample element was previously used to illustrate the importance sampling procedure summarized in this section. 35,36 For future reference, CCDFs constructed for this sample element are shown in Fig. 6. This construction used the activity level probabilities in Table 2 and the normalized releases in Table 3. Further, the rate constant $\lambda$ in the Poisson model for drilling intrusions in Eqs. (10) and (12) and the brine 

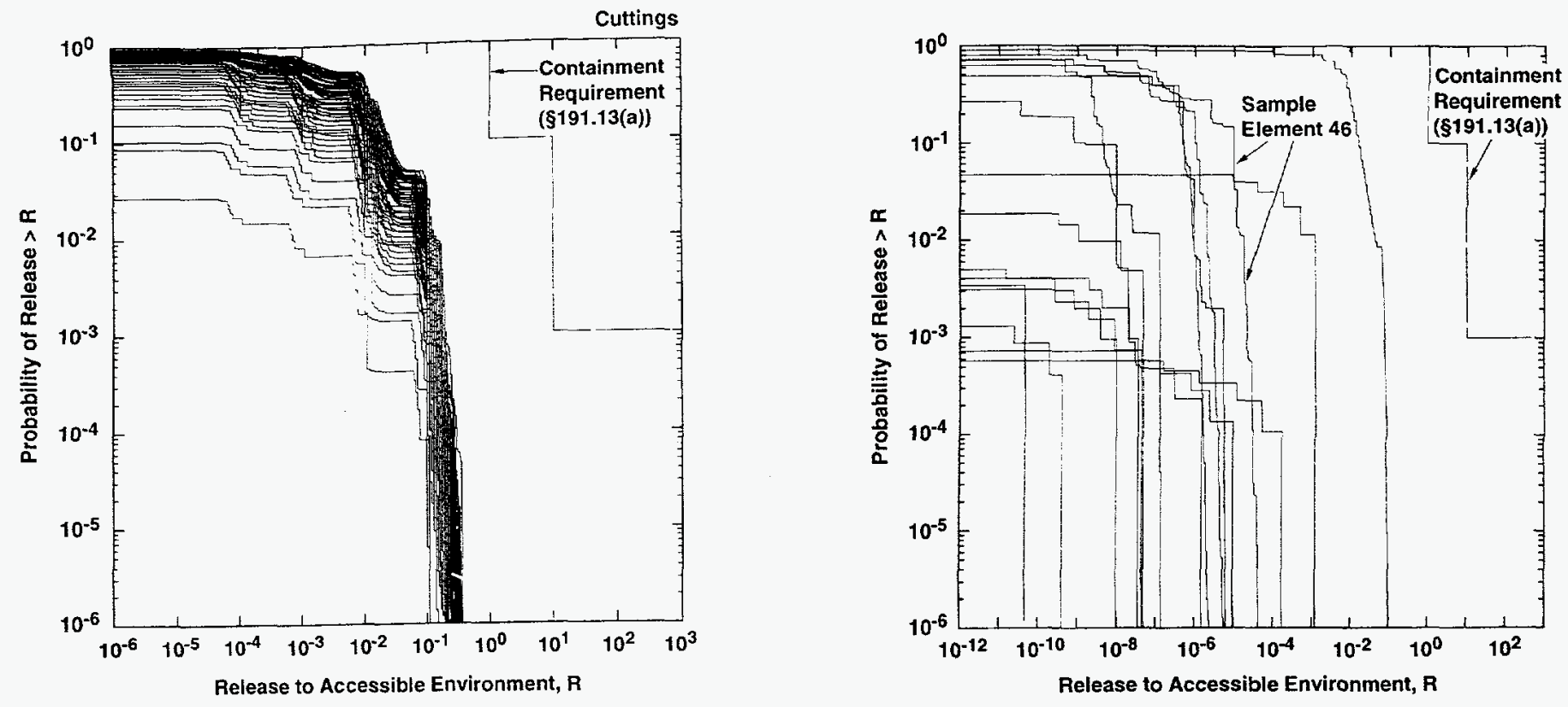

Fig. 5. Distribution of CCDFs for normalized release to the accessible environment due to cuttings removal (left frame) and groundwater transport (right frame) obtained in the 1991 WIPP PA (Ref. 36, Figs. 1 and 2).

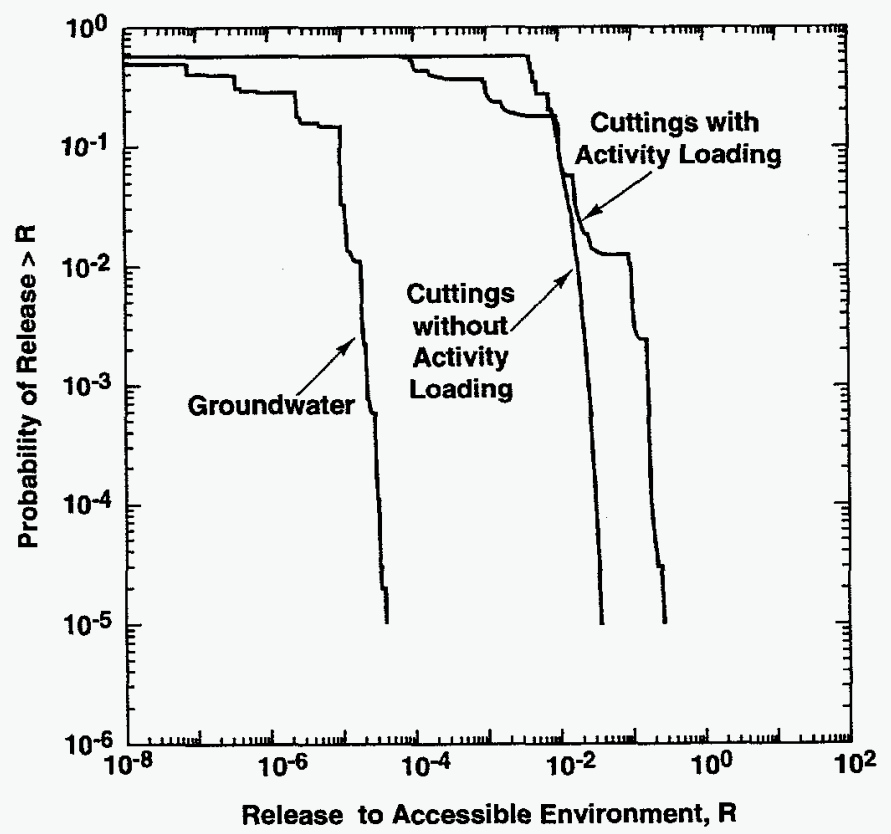

Fig. 6. Estimated CCDFs for sample element 46 (Ref. 36, Fig. 4). 
Table 2. Projected Activity Levels $\left(\mathrm{Ci} / \mathrm{m}^{2}\right)$ in Waste That is Currently Stored and May Be Shipped to the WIPP (Ref. 35, Table 5; based on the Table 3.4-11 of Ref. 22)

\begin{tabular}{|c|c|c|c|c|c|c|c|c|}
\hline \multirow{2}{*}{$\begin{array}{c}\text { Activity } \\
\text { level }\end{array}$} & \multirow[t]{2}{*}{ Type $^{\mathrm{a}}$} & \multirow{2}{*}{$\begin{array}{l}\text { Proba } \\
\text { bilityb }\end{array}$} & \multicolumn{6}{|c|}{ Time (years) } \\
\hline & & & 0 & 1000 & 3000 & 5000 & 7000 & 9000 \\
\hline 1 & $\mathrm{CH}$ & 0.4023 & 3.4833 & 0.2718 & 0.1840 & 0.1688 & 0.1575 & $0 \cdot 1473$ \\
\hline 2 & $\mathrm{CH}$ & 0.2998 & 34.8326 & 2.7177 & 1.8401 & 1.6875 & 1.5748 & 1.4729 \\
\hline 3 & $\mathrm{CH}$ & 0.2242 & $348 \cdot 326$ & $27 \cdot 177$ & $18 \cdot 401$ & $16 \cdot 875$ & $15 \cdot 748$ & 14.729 \\
\hline 4 & $\mathrm{CH}$ & 0.0149 & $3483 \cdot 26$ & 271.77 & $184 \cdot 01$ & 168.75 & $157 \cdot 48$ & $147 \cdot 29$ \\
\hline 5 & RH & 0.0588 & 117.6717 & 0.1546 & 0.1212 & $0 \cdot 1139$ & $0 \cdot 1082$ & $0 \cdot 1030$ \\
\hline \multicolumn{3}{|c|}{ Average for $\mathrm{CH}$ waste: } & 150.7905 & 11.7648 & 7.9658 & $7 \cdot 3053$ & 6.8174 & 6.3764 \\
\hline
\end{tabular}

${ }^{a} \mathrm{CH}$ designates contact-handled waste; $\mathrm{RH}$ designates remote-handled waste.

b Probability $p L_{l}$ that a randomly placed borehole through the waste panels will intersect waste of activity level $l, l$ $=1,2,3,4,5$.

Table 3. Normalized Radionuclide Releases Used to Illustrate Scenario Construction Procedures (Ref. 36, Table 4)

\begin{tabular}{ccccccccc}
\hline Time $^{\mathrm{a}}$ & $r G W I_{i}^{\mathrm{b}}$ & $r G W 2_{i}^{\mathrm{c}}$ & $r C_{i}^{\mathrm{d}}$ & $r C_{i 1}^{\mathrm{e}}$ & $r C_{i 2} \mathrm{e}^{\mathrm{e}}$ & $r C_{i 3} \mathrm{e}^{\mathrm{e}}$ & $r C_{i 4} \mathrm{e}^{2}$ & $r C_{i 5}{ }^{\mathrm{e}}$ \\
\hline $1000 \mathrm{yr}$ & $9.92 \mathrm{E}-06$ & $1.48 \mathrm{E}-05$ & $6.96 \mathrm{E}-03$ & $1.71 \mathrm{E}-04$ & $1.71 \mathrm{E}-03$ & $1.71 \mathrm{E}-02$ & $1.71 \mathrm{E}-01$ & $9.71 \mathrm{E}-05$ \\
$3000 \mathrm{yr}$ & $2.51 \mathrm{E}-06$ & $5.08 \mathrm{E}-06$ & $4.72 \mathrm{E}-03$ & $1.16 \mathrm{E}-04$ & $1.16 \mathrm{E}-03$ & $1.16 \mathrm{E}-02$ & $1.16 \mathrm{E}-01$ & $7.61 \mathrm{E}-05$ \\
$5000 \mathrm{yr}$ & $3.61 \mathrm{E}-07$ & $1.34 \mathrm{E}-06$ & $4.33 \mathrm{E}-03$ & $1.06 \mathrm{E}-04$ & $1.06 \mathrm{E}-03$ & $1.06 \mathrm{E}-02$ & $1.06 \mathrm{E}-01$ & $7.16 \mathrm{E}-05$ \\
$7000 \mathrm{yr}$ & $7.72 \mathrm{E}-08$ & $3.16 \mathrm{E}-07$ & $4.04 \mathrm{E}-03$ & $9.92 \mathrm{E}-05$ & $9.92 \mathrm{E}-04$ & $9.92 \mathrm{E}-03$ & $9.92 \mathrm{E}-02$ & $6.80 \mathrm{E}-05$ \\
$9000 \mathrm{yr}$ & $0.00 \mathrm{E}+00$ & $5.08 \mathrm{E}-08$ & $3.78 \mathrm{E}-03$ & $9.28 \mathrm{E}-05$ & $9.28 \mathrm{E}-04$ & $9.28 \mathrm{E}-03$ & $9.28 \mathrm{E}-02$ & $6.47 \mathrm{E}-05$
\end{tabular}

The releases presented in this table were calculated for sample element 46 in the 1991 WIPP PA (see Ref. 21 , Appendix B).

a Time at which intrusion occurs.

b EPA normalized release (dimensionless) to the accessible environment for groundwater transport (with a dual porosity model in the Culebra Dolomite) initiated by a single borehole in time interval $i$ (i.e., an E2-type intrusion).

c EPA normalized release (dimensionless) to the accessible environment for groundwater transport (with a dual porosity model in the Culebra Dolomite) initiated by two boreholes in the same waste panel in time interval $i$, of which one penetrates a pressurized brine pocket and one does not (i.e., an E1E2-type intrusion).

d EPA normalized release (dimensionless) to the surface environment for cuttings removal as a result of a single borehole in time internal $i$ with the assumption that the waste is homogeneous (i.e., waste of various activity levels is not present). Calculation of the $r C_{i}$ used the average activity level shown in Table 2.

e EPA normalized release (dimensionless) to the surface environment for cuttings removal as a result of a single borehole in time internal $i$ that penetrates waste of activity level $l$. Calculation of the $r C_{i l}$ used the activity levels corresponding to $l=1,2,3,4,5$ shown in Table 2 .

pocket area fraction $f B P$ in Eq. (15) were uncertain inputs in the 1991 WIPP PA, with assigned values of $\lambda=8.4424$ $\times 10^{-5} \mathrm{yr}^{-1}$ and $f B P=0.44981$ for sample element 46 . 
This page intentionally left blank. 


\section{Monte Carlo Procedure for CCDF Construction}

Monte Carlo procedures provide an alternative to the importance sampling procedure described in the preceding section for the construction of the CCDF specified in 191.13(a). With such procedures, elements of the sample space $S_{s t}$ are randomly sampled and the associated releases to the accessible environment are estimated. This produces a sequence of results of the form

$$
\left(x_{i}, \mathbf{c S}_{i}\right), i=1,2, \ldots, n R S,
$$

where

$$
\begin{aligned}
x_{i} & =\text { randomly selected element of } S_{s t}, \\
\mathbf{c S} & =\text { vector of consequences associated with } x_{i}, \\
n R S & =\text { number of random samples taken from } S_{s t} .
\end{aligned}
$$

As in the importance sampling procedure indicated in Eq. (16), the vector $\mathbf{C S} \mathbf{S}_{i}$ would typically contain a variety of quantities, including the normalized releases to the accessible environment required in conjunction with 191.13(a). The number of samples $n R S$ could possibly be quite large (e.g., on the order of $10^{5}$ or larger). Once the results in Eq. (31) are generated, CCDFs for the elements of $\mathrm{cS}$ can be constructed as shown in Fig. 3. The probabilities $p S_{i}$ in this construction are given by

$$
p S_{i}=1 / n R S
$$

when random sampling is used to select the $x_{i}$ from $S_{s t}$. As done in the preceding sentence, it is sometimes semantically convenient to refer to $1 / n R S$ as the probability for $x_{i}$; however, this is not technically correct when the $x_{i}$ are generated by random sampling. Each $x_{i}$ has a probability of zero; $1 / n R S$ is not the probability of $x_{i}$, but rather a weight that can be used to estimate distributions and other quantities (e.g., a mean) associated with the $x_{i}$.

Two obvious questions arise in the implementation of the Monte Carlo procedure indicated in Eq. (31): "How to sample the $x_{i}$ from $\mathcal{S}_{s t}$ ?", and "How to obtain the consequence vectors $\mathbf{c S _ { i }}$ ?". Each of these questions is now addressed.

How to sample the $x_{i}$ is addressed first. As indicated in Eq. (2), each element $x$ of $S_{s t}$ contains a description of a possible $10,000 \mathrm{yr}$ sequence of occurrences at the WIPP. In this analysis, drilling intrusions are the only occurrences under consideration. Thus, each element of $\mathcal{S}_{s t}$ is defined by the number of drilling intrusions that occur, the time of each drilling intrusion, the location of each drilling intrusion, and the activity level of the waste encountered by each drilling intrusion. Thus, each element $x$ of $S_{s t}$ is characterized by a vector $\mathbf{c}(x)$ of the form 


$$
\mathbf{c}(x)=\left[t B H_{1}, x B H_{1}, a B H_{1}, t B H_{2}, x B H_{2}, a B H_{2}, \ldots, t B H_{n B H}, x B H_{n B H}, a B H_{n B H}\right]
$$

where

$t B H_{j}=$ time $(\mathrm{yr})$ at which the $j^{\text {th }}$ drilling intrusion occurs,

$x B H_{j}=$ location of the $j^{\text {th }}$ drilling intrusion,

$a B H_{j}=$ activity level of waste $\left(\mathrm{Ci} / \mathrm{m}^{2}\right)$ penetrated by the $j^{\text {th }}$ drilling intrusion,

$n B H=$ number of drilling intrusions,

and the times $t B H_{j}$ are assumed to be ordered so that $t B H_{j} \leq t B H_{j+1}$ for $j=1,2, \ldots, n B H-1$. In the preceding description, only one coordinate (i.e., $x B H_{j}$ ) is used to represent the location of a drilling intrusion due to the rectilinear nature of the waste panels at the WIPP (Fig. 2) and the current level of resolution used in BRAGFLO to model gas and brine behavior in a waste panel. The use of two coordinates (i.e., $x B H_{j}$ and $y B H_{j}$ ) to represent the location of a drilling intrusion is also possible if such resolution is appropriate for the models used to represent the physical processes associated with $x$.

Once an element of $S_{s t}$ is represented as a vector of the form in Eq. (33), sampling from $S_{s t}$ becomes an exercise in randomly sampling numbers from the interval $[0,1]$. The manner in which such sampling can be done to produce the vector $\mathbf{c}(x)$, and hence an element of $x$ of $S_{s t}$, is not unique. The following outlines one possible procedure.

With the assumption that drilling intrusions follow a Poisson process with a rate constant $\lambda$, the probability $\operatorname{prob}(n)$ that exactly $n$ drilling intrusions occur in the time interval $\left[t_{0}, t_{n T}\right]$ is given by

$$
\operatorname{prob}(n)=\left[\left(t_{n T}-t_{0}\right)^{n} \lambda^{n} / n !\right] \exp \left[-\left(t_{n T}-t_{0}\right) \lambda\right]
$$

In PAs for the WIPP, $t_{0}=100 \mathrm{yr}$ due to the assumption of $100 \mathrm{yr}$ of administrative control and $t_{n T}=10,000 \mathrm{yr}$ as specified in 191.13(a). The value for $n B H$ in Eq. (33) can be obtained by randomly sampling a number $r$ from the interval $[0,1]$ and then assigning $n B H$ the smallest integer value for which the inequality

$$
r \leq \sum_{n=0}^{n B H} \operatorname{prob}(n)
$$

is satisfied.

Once a value for $n B H$ is selected, an additional $3 n B H$ random numbers can be used to assign the values for $t B H_{j}, x B H_{j}$ and $a B H_{j}, j=1,2, \ldots, n B H$. Specifically, let $r B H_{j}, r x B H_{j}$ and $r a B H_{j}, j=1,2, \ldots, n B H$, represent numbers randomly selected from the interval $[0,1]$. Then, the $t B H_{j}$ are defined by 


$$
t B H_{j}=t_{0}+r B H_{j}\left(t_{n T}-t_{0}\right)
$$

where $t_{0}=100 \mathrm{yr}$ and $t_{n T}=10,000 \mathrm{yr}$ in recent WIPP PAs. Similarly, the $x B H_{j}$ are defined by

$$
x B H_{j}=r x B H_{j} \text { aTOT }
$$

where aTOT is the total area $\left(\mathrm{m}^{2}\right)$ of the waste panels as defined in conjunction with Eqs. (12) and (13). Finally, $a B H_{j}$ corresponds to penetration of waste of activity level $m$, where $m$ is the smallest integer such that

$$
r a B H_{j} \leq \sum_{l=1}^{m} p L_{l}
$$

and $p L_{l}$ is the probability that a randomly placed drilling intrusion will penetrate waste of activity level $l$.

The definition of $x B H_{j}$ in Eq. (37) permits the determination of both the waste panel penetrated by a drilling intrusion and whether or not a pressurized brine pocket is penetrated. Specifically, the $j^{\text {th }}$ drilling intrusion penetrates waste panel $m$, where $m$ is the smallest integer such that

$$
x B H_{j} \leq \sum_{l=1}^{m} a T O T_{l}
$$

and $a T O T_{l}$ is the area of waste panel $l$ as defined in conjunction with Eqs. (12) and (13). Further, a pressurized brine pocket is penetrated when the inequality

$$
\sum_{l=1}^{m-1} a T O T_{l}<x B H_{j} \leq a B P_{m}+\sum_{l=1}^{m-1} a T O T_{l}
$$

is satisfied, where $a B P_{m}$ is the area $\left(\mathrm{m}^{2}\right)$ of pressurized brine under waste panel $m$.

How to obtain consequence values, in particular normalized releases to the accessible environment, contained in the consequence vectors $\mathbf{C} \boldsymbol{S}_{i}$ is now addressed. The large number of samples that will be required from $S_{s t}$ precludes the use of the models indicated in Fig. 4 to perform a release calculation for every $x_{i}$ sampled from $S_{s t}$. Rather, it is necessary to perform a limited number of detailed calculations with the models indicated in Fig. 4 and then use the results of these calculations to construct the releases associated with the individual $x_{i}$. There is nothing novel in this. The same type of process was also needed in the importance sampling procedure described in the preceding section. Indeed, the example in this section will use the same release results (i.e., $r C_{i}, r C_{i l}, r G W 1_{i}, r G W 2_{i}$ in Eqs. (17) - (20)) that underlie the example used to illustrate importance sampling. 
The normalized release to the accessible environment $n R(x)$ for an element $x$ of $S_{s t}$ is given by

$$
n R(x)=n R C(x)+n R G(x)
$$

where

$n R C(x)=$ normalized release to the accessible environment due to cuttings removal,

$n R G(x)=$ normalized release to the accessible environment due to groundwater transport.

The releases $n R C(x)$ and $n R G(x)$ can be determined separately and then summed to obtain $n R(x)$.

Definition of the cuttings release $n R C(x)$ is considered first. The assumption is made that no synergisms exist between the cuttings releases associated with individual drilling intrusions; specifically, the releases associated with individual drilling intrusions are assumed to be unaffected by any other drilling intrusions that may occur. When the effects of activity loading are included, $n R C(x)$ is defined by

$$
n R C(x)=\sum_{j=1}^{n B H} r C_{m(j), l(j)}
$$

with the vectors $\mathbf{I}$ and $\mathbf{m}$ defined for $x$ as indicated in Eqs. (9) and (22), respectively. The preceding is the same as the cuttings component of the releases defined in Eqs. (23) and (25) for use with the importance sampling procedure. If the effects of activity loading are not included, $n R C(x)$ is defined by

$$
n R C(x)=\sum_{j=1}^{n B H} r C_{m(j)},
$$

which is the same as the cuttings component of the releases defined in Eqs. (21) and (24) for use with the importance sampling procedure.

Definition of the groundwater release $n R G(x)$ is now considered. A number of assumptions as summarized in Table 4 are made to provide a basis for the use of the releases $r G W 1_{i}$ and $r G W 2_{i}$ in Eqs. (19) and (20) in the construction of a release $n R G(x)$ for an arbitrary element $x$ from $S_{s t}$. Assumption 1 implies that the releases from the individual waste panels can be considered separately. As a result, it is convenient to express $n R G(x)$ in the form

$$
n R G(x)=\sum_{l=1}^{n P} n R G_{l}(x),
$$


Table 4. Assumptions Used in Construction of Groundwater Release to the Accessible Environment $n R G(x)$ for an Arbitrary Element $x$ of $S_{s t}$

\begin{tabular}{cl}
\hline Assumption & \multicolumn{1}{c}{ Description } \\
\hline 1 & $\begin{array}{l}\text { Waste panels are isolated in the sense that the releases that occur from one waste panel are } \\
\text { unaffected by the drilling intrusions that may occur into other waste panels. }\end{array}$ \\
2 & Single drilling intrusions that penetrate a pressurized brine pocket (i.e., an E1 intrusion in WIPP \\
terminology) and single drilling intrusions that do not penetrate a pressurized brine pocket (i.e., \\
an E2 intrusion in WIPP terminology) have the same releases. This may not be an appropriate \\
assumption because the waste panel will fill with brine more rapidly for an E1 than an E2 \\
intrusion (Ref. 37, Sect. IV.D). However, this assumption was made in the 1991 and 1992 \\
WIPP PAs. \\
Multiple E1 intrusions into a waste panel have the same release as the single earliest intrusion. \\
Similarly, multiple E2 intrusions into a waste panel have the same release as the single earliest \\
intrusion. This assumption derives from the fact that brine from the Salado Formation \\
transports radionuclides to an intruding borehole and multiple boreholes will not increase the \\
amount of this brine available for radionuclide transport within a panel. \\
A release involving at least one drilling intrusion that penetrates a pressurized brine pocket and \\
at least one drilling intrusion that does not penetrate a pressurized brine pocket (i.e., an E1E2 \\
intrusion in WIPP terminology) begins at the earliest time at which both an E1 and an E2 \\
intrusion have occurred. \\
$\begin{array}{l}\text { An E1E2 intrusion into a waste panel involving more than 2 drilling intrusions has the same } \\
\text { release as an E1E2 intrusion involving exactly } 2 \text { drilling intrusions. As in Assumption 3, this } \\
\text { assumption derives from the amount of brine available for radionuclide transport within a waste } \\
\text { panel. }\end{array}$
\end{tabular}

where

$n R G_{l}(x)=$ normalized release to accessible environment associated with $x$ due to groundwater transport for radionuclides originating from waste panel $l$.

The releases $n R G_{l}(x)$ can then be determined separately and summed to obtain $n R G(x)$. To facilitate this determination, let

$$
\mathbf{v}_{l}(x)=\left[t_{l}(1), m_{l}(1), b_{l}(1), t_{l}(2), m_{l}(2), b_{l}(2), \ldots, t_{l}\left(n B H_{l}\right), m_{l}\left(n B H_{l}\right), b_{l}\left(n B H_{l}\right)\right]
$$

where

$t_{l}(j)=$ time $(\mathrm{yr})$ at which the $j^{\text {th }}$ drilling intrusion into waste panel $l$ occurs,

$m_{l}(j)=i$ implies that the $j^{\text {th }}$ drilling intrusion into waste panel $l$ occurs in time interval $\left[t_{i-1}, t_{i}\right]$

$b_{l}(j)= \begin{cases}1 & \text { if the } j^{\text {th }} \text { drilling intrusion into waste panel } l \text { penetrates a pressurized brine pocket } \\ 0 & \text { otherwise, }\end{cases}$ 
$n B H_{l}=$ number of drilling intrusions into waste panel $l$,

and the intrusion times $t_{l}(j)$ are assumed to be ordered to that $t_{l}(j) \leq t_{l}(j+1)$ for $j=1,2, \ldots, n B H_{l}-1$. The vector $\mathbf{v}(x)$ can be constructed from information in the definition of $\mathrm{c}(x)$ in Eq. (33).

Four possibilities exist. First, $n B H_{l}=0$. In this case, no groundwater release occurs and

$$
n R G_{l}(x)=0
$$

Second, $n B H_{l} \neq 0$ and all drilling intrusions penetrate a pressurized brine pocket (i.e., $b_{l}(j)=1$ for $j=1,2, \ldots$, $\left.n B H_{l}\right)$. Third, $n B H_{l} \neq 0$ and none of the drilling intrusions penetrate a pressurized brine pocket $\left(i . e ., b_{l}(j)=0\right.$ for $j=$ $1,2, \ldots, n B H_{l}$ ). From Assumption 2 in Table 4, the two preceding cases will have the same release. Further, from Assumption 3 , the release from the waste panel is the release for the earliest intrusion. Thus, the release for the two preceding cases is

$$
n R G_{l}(x)=r G W I_{m_{l}(1)}
$$

Fourth, $n B H_{l} \geq 2$, at least one drilling intrusion penetrates a pressurized brine pocket (i.e., $b_{l}(j)=1$ for at least one $j$ ) and at least one drilling intrusion does not penetrate a pressurized brine pocket (i.e., $b_{l}(j)=0$ for at least one $j$ ). Let $j E 1 E 2$ be the smallest integer such that the sequence $b_{l}(1), b_{l}(2), \ldots, b_{l}(j E 1 E 2)$ contains both 0 's and 1 's (i.e., $\left[t_{0}\right.$, $\left.t_{l}(j E I E 2)\right]$ is the shortest time interval associated with $x$ that includes at least one drilling intrusion that penetrates a pressurized brine pocket and at least one drilling intrusion that does not penetrate a pressurized brine pocket). The release for this case is approximated by

$$
n R G_{l}(x)=\left(r G W I_{m_{l}(1)}-r G W I_{m_{l}(j E I E 2)}\right)+r G W 2_{m_{l}(j E 1 E 2)}
$$

The first term on the right in Eq. (48) is the release that takes place before the occurrence of an E1E2-type intrusion and derives from Assumptions 2 and 3. The second term on the right in Eq. (48) is the release that takes place after the occurrence of an E1E2-type intrusion and derives from Assumptions 4 and 5.

A Monte Carlo procedure for the construction of the CCDF specified in 191.13(a) has been described. The results for sample element 46 in the 1991 WIPP PA are now used to illustrate this procedure. Specifically, vectors of the form $\mathbf{c}(x)$ indicated in Eq. (33) are randomly selected with $\lambda=8.4424 \times 10^{-5} \mathrm{yr}^{-1}$ (i.e., the value for $\lambda$ in sample element 46), the waste panel areas in Table 5, and the activity level probabilities in Table 2 . Once c(x) is obtained, the vectors $\mathbf{v}_{l}(x)$ in Eq. (45) are constructed. In this construction, a brine pocket area fraction of $f B P=$ 0.44981 is used in consistency with the 1991 WIPP PA (see Eq. (15)), which is the sampled value for sample element 46. Given $\mathbf{c}(x)$ and $\mathbf{v}_{l}(x)$, the associated normalized releases $n R(x), n R C(x), n R G(x)$ and $n R G_{l}(x)$ are then 
Table 5. Parameter Values Used in Example Calculation of Probabilities for E1E2-Type Scenarios (Ref. 35, Table 4; adapted from Table 5.1-1 of Ref. 22 with depth to pressurized brine assumed to be less than $1250 \mathrm{~m}$ )

\begin{tabular}{lrrr}
\hline & $a T O T_{l}^{\mathrm{a}}$ & $a B P_{l}^{\mathrm{b}}$ & $a B P_{l} / a T O T_{l}$ \\
\hline Panel 1 & 11530 & 11530 & 1.0000 \\
Panel 2 & 11530 & 8249 & 0.7154 \\
Panel 3 & 11530 & 3548 & 0.3077 \\
Panel 4 & 11530 & 8869 & 0.7692 \\
Panel 5 & 11530 & 4833 & 0.4192 \\
Panel 6 & 11530 & 0 & 0.0000 \\
Panel 7 & 11530 & 0 & 0.0000 \\
Panel 8 & 11530 & 7432 & 0.6446 \\
Southern panel & 8413 & 3786 & 0.4500 \\
Northern panel & 8701 & 1044 & 0.1200
\end{tabular}

Additional values:

$$
\begin{aligned}
& a T O T=\sum_{l=1}^{10} a T O T_{l}=109354 \\
& a B P=\sum_{l=1}^{10} a B P_{l}=49291 \\
& f B P=a B P / a T O T=0.45075
\end{aligned}
$$

constructed from the results in Table 3 as indicated in Eqs. (41) - (48). The outcome of this procedure is a sequence of results of the form shown in Eq. (31). Due to the large number of samples in use (i.e., $n R S$ ), the results $\mathbf{C S}_{i}$ for the individual $x_{i}$ sampled from $S_{s t}$ are not saved; instead, a binning procedure is used whereby the range of each release is subdivided into intervals and the number of releases falling into each interval is accumulated. This binning procedure was also used in the importance sampling procedure described in the preceding section due to the large number of strata involved.

As shown in Fig. 7, the importance sampling procedure implemented with the program CCDFPERM ${ }^{36}$ described in Sect. 2 and the Monte Carlo procedure described in this section produce similar results. The CCDFs for cuttings removal for waste of average activity level are essentially identical. The CCDFs for cuttings removal for waste of different activity levels are also similar. There is some separation between the two CCDFs for groundwater transport because the Monte Carlo simulation is using a less restrictive definition of an E1E2-type intrusion. Specifically, the drilling intrusions that produce an E1E2-type intrusion are not required to fall in the time intervals $[100,2000 \mathrm{yr}],[2000,4000 \mathrm{yr}],[4000,6000 \mathrm{yr}],[6000,8000 \mathrm{yr}]$ and $[8000,10,000 \mathrm{yr}]$ used to define E1E2-type intrusions in the importance sampling procedure. In addition, the Monte Carlo procedure includes the 


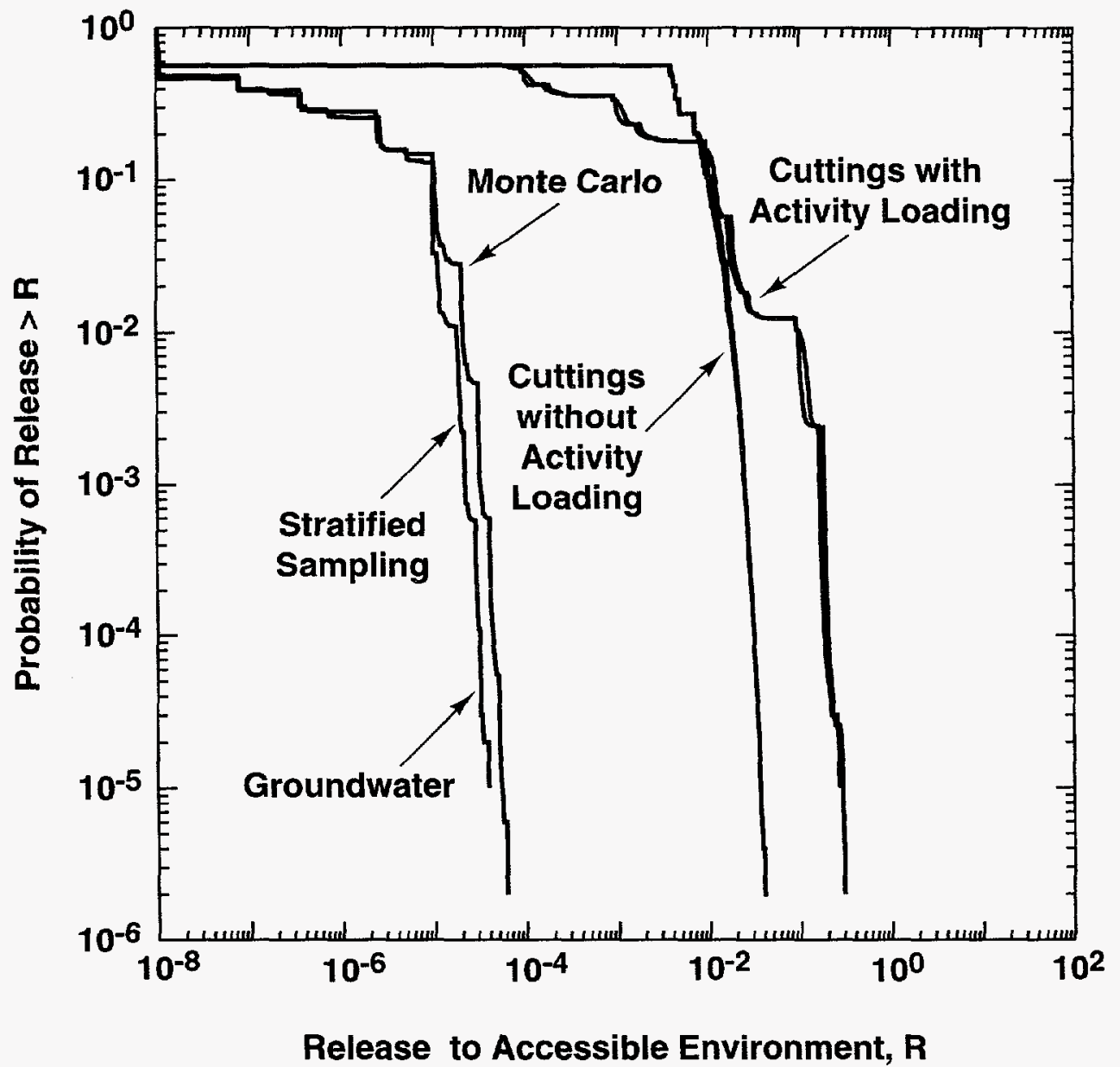

TRI-6342-4337-0

Fig. 7. Estimated CCDFs for sample element 46 obtained with importance sampling and a Monte Carlo sample of size $5 \times 10^{5}$.

release that takes place before the second borehole associated with an E1E2-type intrusion occurs, allows for the possibility that an E1E2-type intrusion may occur in conjunction with one or more E2-type intrusions for a given element of $S_{s t}$, and also allows for the possibility that more than one E1E2-type intrusion may occur for a given element of $S_{s t}$.

As shown in Fig. 8, the Monte Carlo procedure for CCDF construction has clearly converged with a sample of size $5 \times 10^{5}$. Indeed, adequate resolution for comparison with the EPA release limits is obtained with a much smaller sample size (i.e., between $5 \times 10^{3}$ and $5 \times 10^{4}$ ). The evaluation of the three CCDFs in Fig. 8 with a sample of size $5 \times 10^{5}$ required approximately $27 \mathrm{~s}$ on a Digital Vax Alpha using VMS. Thus, the computational requirements associated with the Monte Carlo procedure for CCDF construction described in this presentation are quite reasonable. In particular, the computational cost associated with the Monte Carlo procedure is acceptable for the construction of distributions of CCDFs of the form shown in Fig. 5. 


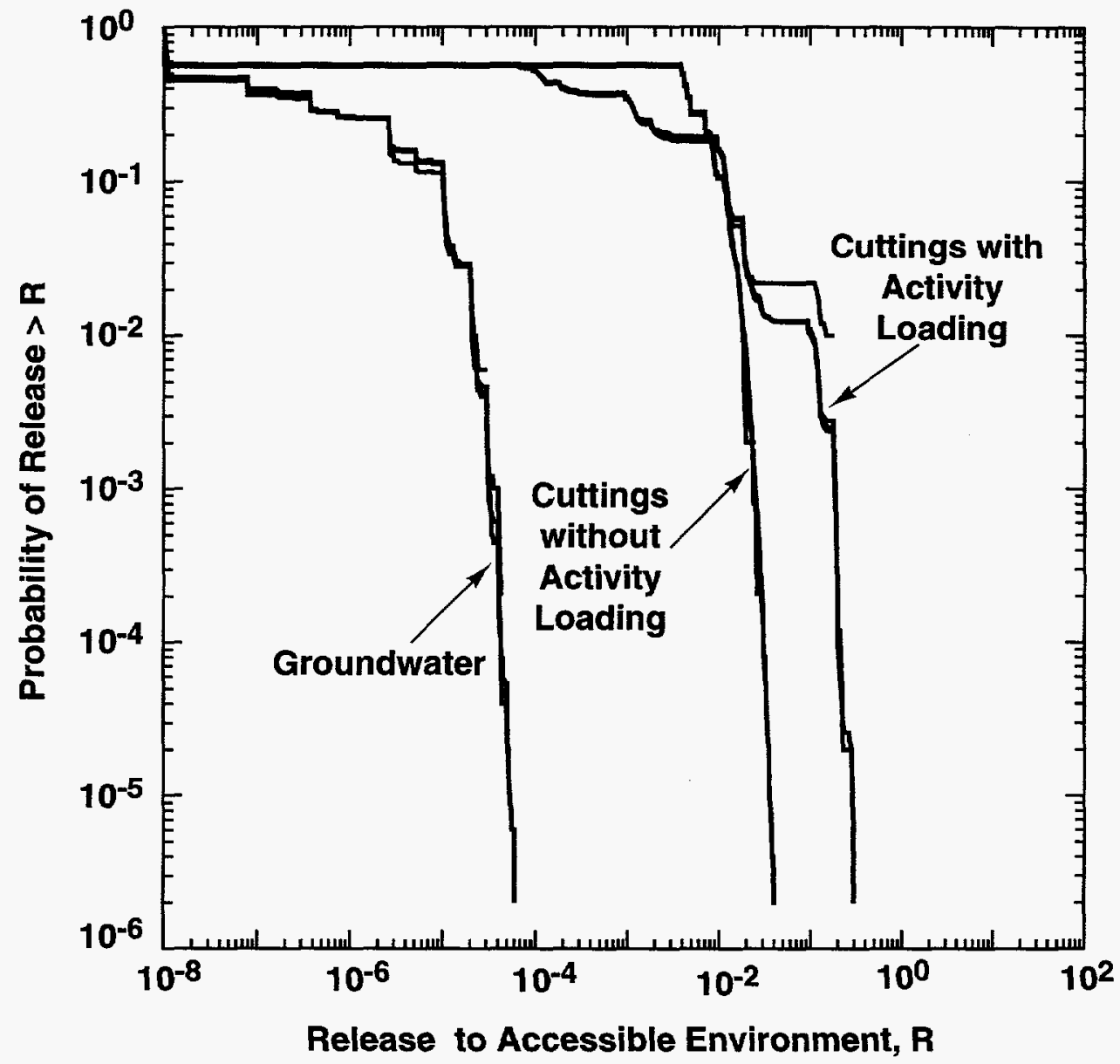

TRI-6342-4338-0

Fig. 8. Estimated CCDFs for sample element 46 obtained with Monte Carlo samples of size $5 \times 10^{2}, 5 \times 10^{3}, 5 \times$ $10^{4}$ and $5 \times 10^{5}$. 
This page intentionally left blank. 


\section{Monte Carlo Estimation of Scenario Probabilities}

Scenarios that involve E1E2-type intrusions are important in PAs for the WIPP because of the potentially large releases associated with these intrusions. Large releases may result because of brine flow up an intruding borehole from a pressurized brine pocket, through a waste panel, and then up a second borehole to the Culebra Dolomite. Such flow has the potential to access more of the radionuclide inventory in a waste panel than a single borehole or multiple boreholes that do not involve cross flow between the individual boreholes.

Due to the complexity of the problem (i.e., multiple waste panels, different areas of pressurized brine under individual waste panels, drilling intrusions at different times and locations), the derivation of exact formulas for the probability of scenarios that involve E1E2-type intrusions is difficult. Formulas such as the one given in Eq. (12) and used in 1991 and 1992 WIPP PAs are approximations whose accuracy is difficult to verify with analytic procedures. In contrast, Monte Carlo procedures of the type discussed in the preceding section provide a relatively simple means of obtaining accurate approximations of the probability of such scenarios.

Examples of probabilities for scenarios involving E1E2-type intrusions are shown in Table 6. Scenarios of the form $\mathcal{S}^{+-}(t, t+\Delta t)$ are defined in Eq. (5) and involve intrusion of a waste panel during the time interval $[t, t+\Delta t]$ by two or more boreholes, with at least one of these boreholes penetrating a pressurized brine pocket and at least one of these boreholes not penetrating a pressurized brine pocket. For perspective, a scenario denoted by $\mathcal{S}^{+}(t, t+\Delta t)$ is also considered, where

$\mathcal{S}^{+}(t, t+\Delta t)=\left\{x: x\right.$ an element of $\mathcal{S}_{s t}$ for which two or more boreholes penetrate the same waste panel during the time interval $[t, t+\Delta t]$, with at least one of these boreholes penetrating a pressurized brine pocket\}.

The scenarios $S^{+-}(t, t+\Delta t)$ and $S^{+}(t, t+\Delta t)$ differ in that only penetration of a pressurized brine pocket is required in the definition of $\mathcal{S}^{+}(t, t+\Delta t)$. As examination of Table 6 shows, (1) the approximate formula in Eq. (12) for the probability of $S^{4-}(t, t+\Delta t)$ provides results close to those obtained in the Monte Carlo simulation, (2) probabilities for $S^{+}(t, t+\Delta t)$ are somewhat higher than those for $S^{+-}(t, t+\Delta t)$, (3) probabilities for $S^{+-}(t, t+\Delta t)$ can be large when the entire $9900 \mathrm{yr}$ period is considered, (4) probabilities for $\mathcal{S}^{+-}(t, t+\Delta t)$ are small when $\Delta t \leq 500 \mathrm{yr}$, (5) the probability of $S^{+-}(t, t+\Delta t)$ decreases as $\lambda$ increases, and (6) the use of panel-dependent brine pocket area fractions produces somewhat smaller probabilities for $\mathcal{S}^{4-}(t, t+\Delta t)$ than the use of a single average brine pocket area fraction.

The probabilities in Table 6 are for the scenarios $S^{4-}(t, t+\Delta t)$ and $S^{+}(t, t+\Delta t)$ and thus involve drilling intrusions that occur within the time interval $[t, t+\Delta t]$. Another way to define scenarios that involve E1E2-type intrusions is on the basis of the time of separation between the drilling intrusions. Specifically, scenarios $\mathcal{S}^{+-}(\Delta t)$ and $S^{4}(\Delta t)$ can be defined by 
Table 6. Comparison of Probabilities for Scenarios Involving E1E2-Type Intrusions That Occur with Fixed Time Intervals for the Defining Boreholes

\begin{tabular}{ccccccc}
\hline $\begin{array}{c}\text { Time Interval } \\
{[t, t+\Delta t]}\end{array}$ & $\begin{array}{c}p S_{A}^{+-}(t, t+\Delta t)^{\mathrm{a}} \\
\lambda=3.28 \times 10^{-4} \mathrm{yr}^{-1}\end{array}$ & $\begin{array}{c}p S_{M}^{+-}(t, t+\Delta t)^{\mathrm{b}} \\
\lambda=3.28 \times 10^{-4} \mathrm{yr}^{-1}\end{array}$ & $\begin{array}{c}p S_{M}^{+}(t, t+\Delta t)^{\mathrm{C}} \\
\lambda=3.28 \times 10^{-4} \mathrm{yr}^{-1}\end{array}$ & $\begin{array}{c}p S_{A}^{+-}(t, t+\Delta t) \\
\lambda=8.44 \times 10^{-4} \mathrm{yr}^{-1}\end{array}$ & $\begin{array}{c}p S_{M}^{++}(t, t+\Delta t) \\
\lambda=8.44 \times 10^{-5} \mathrm{yr}^{-1}\end{array}$ & $\begin{array}{c}p S_{M}^{+}(t, t+\Delta t) \\
\lambda=8.44 \times 10^{-5} \mathrm{yr}^{-1}\end{array}$ \\
\hline \multicolumn{7}{c}{ Constant Brine Pocket Area Fraction: $f B P=0.45075($ Table 5) } \\
{$[t, t+100 \mathrm{yr}]$} & $2.69 \times 10^{-5}$ & $2.40 \times 10^{-5 \mathrm{~d}}$ & $3.40 \times 10^{-5}$ & $1.78 \times 10^{-6}$ & 0.00 & $1.00 \times 10^{-6}$ \\
{$[t, t+500 \mathrm{yr}]$} & $6.68 \times 10^{-4}$ & $6.20 \times 10^{-4}$ & $8.79 \times 10^{-4}$ & $4.45 \times 10^{-5}$ & $5.00 \times 10^{-5}$ & $6.60 \times 10^{-5}$ \\
{$[t, t+1000 \mathrm{yr}]$} & $2.65 \times 10^{-3}$ & $2.61 \times 10^{-3}$ & $3.65 \times 10^{-3}$ & $1.78 \times 10^{-4}$ & $1.89 \times 10^{-4}$ & $2.49 \times 10^{-4}$ \\
{$[t, t+2000 \mathrm{yr}]$} & $1.04 \times 10^{-2}$ & $1.02 \times 10^{-2}$ & $1.43 \times 10^{-2}$ & $7.08 \times 10^{-4}$ & $7.33 \times 10^{-4}$ & $9.85 \times 10^{-4}$ \\
{$[t, t+5000 \mathrm{yr}]$} & $6.20 \times 10^{-2}$ & $6.00 \times 10^{-2}$ & $8.25 \times 10^{-2}$ & $4.37 \times 10^{-3}$ & $4.37 \times 10^{-3}$ & $6.11 \times 10^{-3}$ \\
{$[t, t+9900 \mathrm{yr}]$} & $2.24 \times 10^{-1}$ & $2.02 \times 10^{-1}$ & $2.67 \times 10^{-1}$ & $1.68 \times 10^{-2}$ & $1.68 \times 10^{-2}$ & $2.34 \times 10^{-2}$ \\
\multicolumn{7}{c}{} \\
{$[t, t+100 \mathrm{yr}]$} & $1.50 \times 10^{-5}$ & $1.00 \times 10^{-5}$ & $2.40 \times 10^{-5}$ & $9.96 \times 10^{-7}$ & 0.00 & $1.00 \times 10^{-6}$ \\
{$[t, t+500 \mathrm{yr}]$} & $3.73 \times 10^{-4}$ & $3.74 \times 10^{-4}$ & $7.57 \times 10^{-4}$ & $2.49 \times 10^{-5}$ & $2.90 \times 10^{-5}$ & $5.60 \times 10^{-5}$ \\
{$[t, t+1000 \mathrm{yr}]$} & $1.48 \times 10^{-3}$ & $1.46 \times 10^{-3}$ & $3.16 \times 10^{-3}$ & $9.92 \times 10^{-5}$ & $1.06 \times 10^{-4}$ & $1.97 \times 10^{-4}$ \\
{$[t, t+2000 \mathrm{yr}]$} & $5.82 \times 10^{-3}$ & $5.68 \times 10^{-3}$ & $1.22 \times 10^{-2}$ & $3.95 \times 10^{-4}$ & $4.22 \times 10^{-4}$ & $8.38 \times 10^{-4}$ \\
{$[t, t+5000 \mathrm{yr}]$} & $3.47 \times 10^{-2}$ & $3.41 \times 10^{-2}$ & $7.07 \times 10^{-2}$ & $2.44 \times 10^{-3}$ & $2.49 \times 10^{-3}$ & $5.20 \times 10^{-3}$ \\
{$[t, t+9900 \mathrm{yr}]$} & $1.26 \times 10^{-1}$ & $1.19 \times 10^{-1}$ & $2.31 \times 10^{-1}$ & $9.37 \times 10^{-3}$ & $9.57 \times 10^{-3}$ & $1.99 \times 10^{-2}$
\end{tabular}

a Probability for scenario $S^{+-}(t, t+\Delta t)$ calculated as shown in Eq. (12), with the subscript A selected to indicate "approximate".

b Probability for scenario $S^{+-}(t, t+\Delta t)$ calculated with Monte Carlo procedure described in Sect. 3 and a sample size of $1 \times 10^{6}$, with the subscript $M$ selected to indicate "Monte Carlo".

c Probability for scenario $\mathcal{S}^{+}(t, t+\Delta t)$ calculated with Monte Carlo procedure described in Sect. 3 and a sample size of 1 $\times 10^{6}$, with the subscript $M$ selected to indicate "Monte Carlo".

d An approximate $100(1-\alpha) \%$ confidence interval is given by $Y / n \pm x_{1-\alpha / 2}\left[Y(n-Y) / n^{3}\right]^{1 / 2}$, where $Y$ is number of times event occurred (e.g., 24 for $S^{+-}(t, t+100)$ and $\left.\lambda=3.28 \times 10^{-4} \mathrm{yr}^{-1}\right), x_{1-\alpha / 2}$ is quantile of normal distribution (e.g., 1.96 for $95 \%$ confidence interval) and $n$ is sample size (e.g., $1 \times 10^{6}$ in present analysis) (Ref. 47, pp. 99-100, Method C). Thus, the $95 \%$ confidence interval for $p S_{M}^{+-}(t, t+100)$ with $\lambda=3.28 \times 10^{-4} \mathrm{yr}^{-1}$ is $2.40 \times 10^{-5} \pm 0.96 \times 10^{-5}$.

$\mathcal{S}^{+-}(\Delta t)=\left\{x: \quad x\right.$ an element of $\mathcal{S}_{s t}$ for which two or more boreholes penetrate the same waste panel, with at least one of these boreholes penetrating a pressurized brine pocket, at least one borehole not penetrating a pressurized brine pocket, and the minimum time of separation between a borehole that penetrates a pressurized brine pocket and a borehole that does not penetrate a pressurized brine pocket less than $\Delta t\}$

and

$\mathcal{S}^{+}(\Delta t)=\left\{x: \quad x\right.$ an element of $S_{s t}$ for which two or more boreholes penetrate the same waste panel, with at least one borehole penetrating a pressurized brine pocket, and the minimum time of separation between a borehole that penetrates a pressurized brine pocket and any other borehole is less than $\Delta t$ \} 
Probabilities for $\mathcal{S}^{+-}(\Delta t)$ and $\mathcal{S}^{+}(\Delta t)$ are shown in Table 7 . As examination of Table 7 shows, the probability of scenarios involving E1E2-type scenarios decreases as the allowed time of separation between the defining boreholes decreases. Indeed, scenarios involving E1E2-type scenarios almost go away (i.e., have probabilities approaching or less than $10^{-3}$ ) if an argument can be made that the defining intrusions must occur within $100 \mathrm{yr}$ of each other.

Table 7. Comparison of Probabilities for Scenarios Involving E1E2-Type Intrusions That Occur with Fixed Separation Times for the Defining Boreholes

\begin{tabular}{|c|c|c|c|c|}
\hline $\begin{array}{l}\text { Separation } \\
\text { Time } \\
\Delta t\end{array}$ & $\begin{array}{c}p S_{M}^{+-}(\Delta t)^{\mathrm{a}} \\
\lambda=3.28 \times 10^{-4} \mathrm{yr}^{-1}\end{array}$ & $\begin{array}{c}p S_{M}^{+}(\Delta t)^{\mathrm{b}} \\
\lambda=3.28 \times 10^{-4} \mathrm{yr}^{-1}\end{array}$ & $\begin{array}{c}p S_{M}^{+-}(\Delta t) \\
\lambda=8.44 \times 10^{-5} \mathrm{yr}^{-1}\end{array}$ & $\begin{array}{c}p S_{M}^{+}(\Delta t) \\
\lambda=8.44 \times 10^{-5} \mathrm{yr}^{-1}\end{array}$ \\
\hline \multicolumn{5}{|c|}{ Constant Brine Pocket Area Fraction: $f B P=0.45075$ (Table 5) } \\
\hline $100 \mathrm{yr}$ & $5.18 \times 10^{-3}$ & $7.26 \times 10^{-3}$ & $3.39 \times 10^{-4}$ & $4.65 \times 10^{-4}$ \\
\hline $500 \mathrm{yr}$ & $2.50 \times 10^{-2}$ & $3.50 \times 10^{-2}$ & $1.70 \times 10^{-3}$ & $2.39 \times 10^{-3}$ \\
\hline $1000 \mathrm{yr}$ & $4.79 \times 10^{-2}$ & $6.62 \times 10^{-2}$ & $3.33 \times 10^{-3}$ & $4.66 \times 10^{-3}$ \\
\hline $2000 \mathrm{yr}$ & $8.63 \times 10^{-2}$ & $1.18 \times 10^{-1}$ & $6.33 \times 10^{-3}$ & $8.84 \times 10^{-3}$ \\
\hline $5000 \mathrm{yr}$ & $1.61 \times 10^{-1}$ & $2.14 \times 10^{-1}$ & $1.27 \times 10^{-2}$ & $1.77 \times 10^{-2}$ \\
\hline $9900 \mathrm{yr}$ & $2.02 \times 10^{-1}$ & $2.67 \times 10^{-1}$ & $1.68 \times 10^{-2}$ & $2.34 \times 10^{-2}$ \\
\hline \multicolumn{5}{|c|}{ Panel-Dependent Brine Pocket Area Fractions: $f B P_{l}=a B P_{l} / a T O T_{l}($ Table 5) } \\
\hline $100 \mathrm{yr}$ & $2.92 \times 10^{-3}$ & $6.30 \times 10^{-3}$ & $1.80 \times 10^{-4}$ & $3.99 \times 10^{-4}$ \\
\hline $500 \mathrm{yr}$ & $1.41 \times 10^{-2}$ & $3.02 \times 10^{-2}$ & $9.95 \times 10^{-4}$ & $2.05 \times 10^{-3}$ \\
\hline $1000 \mathrm{yr}$ & $2.70 \times 10^{-2}$ & $5.69 \times 10^{-2}$ & $1.89 \times 10^{-3}$ & $3.96 \times 10^{-3}$ \\
\hline $2000 \mathrm{yr}$ & $4.92 \times 10^{-2}$ & $1.01 \times 10^{-1}$ & $3.56 \times 10^{-3}$ & $7.52 \times 10^{-3}$ \\
\hline $5000 \mathrm{yr}$ & $9.39 \times 10^{-2}$ & $1.85 \times 10^{-1}$ & $7.22 \times 10^{-3}$ & $1.51 \times 10^{-2}$ \\
\hline $9900 \mathrm{yr}$ & $1.19 \times 10^{-1}$ & $2.31 \times 10^{-1}$ & $9.57 \times 10^{-3}$ & $1.99 \times 10^{-2}$ \\
\hline $\begin{array}{l}\text { a Probability fo } \\
\text { size of } 1 \times 10^{6} \text {, } \\
\text { b Probability fo } \\
\text { size of } 1 \times 10^{6} \text {, }\end{array}$ & \multicolumn{4}{|c|}{$\begin{array}{l}\text { io } \mathcal{S}^{+-}(\Delta t) \text { calculated with Monte Carlo procedure described in Sect. } 3 \text { and a sample } \\
\text { subscript M selected to indicate "Monte Carlo". } \\
\text { rio } \mathcal{S}^{+}(\Delta t) \text { calculated with Monte Carlo procedure described in Sect. } 3 \text { and a sample } \\
\text { subscript M selected to indicate "Monte Carlo". }\end{array}$} \\
\hline
\end{tabular}


This page intentionally left blank. 


\section{Discussion and Prospectus}

A Monte Carlo procedure for the construction of CCDFs for comparison with the EPA release limits for radioactive waste disposal has been illustrated. Conceptually, this procedure is a numerical (i.e., Monte Carlo) technique for integration over the probability space $S_{s t}$ associated with stochastic uncertainty. In terms of computational cost, the Monte Carlo procedure is competitive with a previously used procedure based on stratified sampling and produces similar results when equivalent integration problems are considered.

Both the Monte Carlo procedure and the stratified sampling procedure make use of a relatively small number of mechanistic calculations, which are then used to construct normalized releases to the accessible environment for the large number of elements of $S_{s t}$ that are considered in the two procedures. The advantage of the Monte Carlo procedure is that it avoids the need to explicitly define subsets of $S_{s t}$ (i.e., strata) and then develop closed-form formulas for the probability of these strata. Rather, $\mathcal{S}_{s t}$ is covered and appropriate probabilities developed through the random sampling associated with the Monte Carlo procedure. In the example contained in this presentation, the Monte Carlo procedure allowed a better calculation of the probabilities and normalized releases associated with E1E2-type scenarios than was obtained with stratified sampling.

In future studies, it is anticipated that the Monte Carlo procedure will allow further refinements over what can be conveniently accomplished with stratified sampling, thus producing more realistic analyses. For example, (1) a distinction can be made between a single borehole that penetrates a pressurized brine pocket and single borehole that does not penetrate a pressurized brine pocket, which is important because a waste panel fills more rapidly with brine when a pressurized brine pocket is penetrated, (2) boreholes can be assumed to close after a specified period of time rather than remaining open permanently as is now done in PAs for the WIPP, (3) E1E2-type scenarios can be assumed to occur only if the necessary boreholes occur sufficiently close together in time, (4) specific flow paths through the waste based on the location of the boreholes associated with E1E2-type scenarios can be included in the analysis rather than conservatively assuming that the flow path associated with such scenarios accesses all waste in a waste panel as is currently done in PAs for the WIPP; the effects of flow paths involving more than one waste panel can also be investigated, (5) borehole permeability can be incorporated into the analysis as a stochastic uncertainty (i.e., all boreholes need not be assumed to have the same permeability as is currently done in PAs for the WIPP), (6) inventory checks on material released from waste panels can be performed to assure that releases do not exceed the available inventory, and (7) interpolation on intrusion time can be used to make more realistic use of the mechanistic calculations on which CCDF construction is ultimately based.

Procedures can also be used to make the Monte Carlo integration over $\mathcal{S}_{s t}$ more efficient. For example, a possibility is to sample a disproportionate number of elements from $S_{s t}$ that involve two or more drilling intrusions and then probabilistically correct for this disproportionate sampling when the derived CCDF is actually constructed. Such procedures (i.e., importance sampling) allow increased resolution in the incorporation of unlikely but risk- 
significant subsets of $S_{s t}$ into the analysis. For example, such a procedure could be used to increase the numerical accuracy with which the effects of E1E2-type scenarios are incorporated into the analysis.

Both the Monte Carlo and stratified sampling procedures described in this presentation rely on a relatively small number of mechanistic calculations, which are then extended to provide estimates of the releases associated with a large number of different elements of $S_{s t}$. Neither procedure would be computationally tractable if a sequence of mechanistic calculations had to be performed for every element of $\mathcal{S}_{s t}$ required in the construction of the CCDF specified in the EPA release limits. The advantage of the Monte Carlo procedure is that it allows greater resolution to be built into the use of these mechanistic calculations. 


\section{References}

1. U.S. EPA (Environmental Protection Agency). 1985. "Environmental Standards for the Management and Disposal of Spent Nuclear Fuel, High-Level and Transuranic Radioactive Wastes; Final Rule, 40 CFR Part 191." Federal Register 50: 38066-38089.

2. U.S. EPA (Environmental Protection Agency). 1993. "Environmental Radiation Protection Standards for the Management and Disposal of Spent Nuclear Fuel, High-Level and Transuranic Radioactive Wastes; Final Rule, 40 CFR Part 191." Federal Register 58: 66398-66416.

3. Farmer, F.R. 1967. "Reactor Safety and Siting: A Proposed Risk Criterion." Nuclear Safety 8: 539-548.

4. Cox, D.C., and P. Baybutt. 1982. "Limit Lines for Risk." Nuclear Technology 57: 320-330.

5. Munera, H.A., and G. Yadigaroglu. 1986. "On Farmer's Line, Probability Density Functions, and Overall Risk." Nuclear Technology 74: 229-232.

6. Chernoff, H., and L.E. Moses. 1959. Elementary Decision Theory. New York, NY: John Wiley and Sons.

7. Kaplan, S., and B.J. Garrick. 1981. "On the Quantitative Definition of Risk." Risk Analysis 1: 11-27.

8. Vesely, W.E., and D.M. Rasmuson. 1984. "Uncertainties in Nuclear Probabilistic Risk Analyses." Risk Analysis 4: 313-322.

9. Paté-Cornell, M.E. 1986. "Probability and Uncertainty in Nuclear Safety Decisions." Nuclear Engineering and Design 93: 319-327.

10. Parry, G.W. 1988. "On the Meaning of Probability in Probabilistic Safety Assessment." Reliability Engineering and System Safety 23: 309-314.

11. IAEA (International Atomic Energy Agency). 1989. Evaluating the Reliability of Predictions Made Using Environmental Transfer Models. Safety Series Report No. 100. Vienna, Austria: International Atomic Energy Agency.

12. Apostolakis, G. 1990. "The Concept of Probability in Safety Assessments of Technological Systems." Science 250: 1359-1364.

13. Breeding, R.J., J.C. Helton, E.D. Gorham, and F.T. Harper. 1992. "Summary Description of the Methods Used in the Probabilistic Risk Assessments for NUREG-1150." Nuclear Engineering and Design 135: 1-27.

14. Helton, J.C. 1993. "Risk, Uncertainty in Risk, and the EPA Release Limits for Radioactive Waste Disposal." Nuclear Technology 101: 18-39.

15. Helton, J.C., and R.J. Breeding. 1993. "Calculation of Reactor Accident Safety Goals." Reliability Engineering and System Safety 39: 129-158.

16. U.S. EPA (Environmental Protection Agency). 1993. An SAB Report: Multi-Media Risk Assessment for Radon, Review of Uncertainty Analysis of Risks Associated with Exposure to Radon. EPA-SAB-RAC-93014. Washington, DC: U.S. Environmental Protection Agency.

17. Feller, W. 1971. An Introduction to Probability Theory and Its Applications, Vol. II, 2nd Ed. New York, NY: John Wiley and Sons.

18. Ash, R.B. 1972. Real Analysis and Probability. New York, NY: Academic Press. 
19. Breiman, L. 1992. Probability. Philadelphia, PA: Society for Industrial and Applied Mathematics.

20. WIPP PA (Performance Assessment) Division. 1991. Preliminary Comparison with 40 CFR Part 191, Subpart B for the Waste Isolation Pilot Plant, December 1991, Volume 1: Methodology and Results. SAND91-0893/1. Albuquerque, NM: Sandia National Laboratories.

21. WIPP PA (Performance Assessment) Division. 1991. Preliminary Comparison with 40 CFR Part 191, Subpart B for the Waste Isolation Pilot Plant, December 1991, Volume 2: Probability and Consequence Modeling. SAND91-0893/2. Albuquerque, NM: Sandia National Laboratories.

22. WIPP PA (Performance Assessment) Division. 1991. Preliminary Comparison with 40 CFR Part 191, Subpart B for the Waste Isolation Pilot Plant, December 1991, Volume 3: Reference Data. SAND910893/3. Albuquerque, NM: Sandia National Laboratories.

23. Helton, J.C., J.W. Garner, R.P. Rechard, D.K. Rudeen, and P.N. Swift. 1992. Preliminary Comparison with 40 CFR Part 191, Subpart B for the Waste Isolation Pilot Plant, December 1991, Volume 4: Uncertainty and Sensitivity Analysis Results. SAND91-0893/4. Albuquerque, NM: Sandia National Laboratories.

24. WIPP PA (Performance Assessment) Department. 1992. Preliminary Performance Assessment for the Waste Isolation Pilot Plant, December 1992-Volume 1: Third Comparison with 40 CFR 191, Subpart B. SAND92-0700/1. Albuquerque, NM: Sandia National Laboratories.

25. WIPP PA (Performance Assessment) Department. 1992. Preliminary Performance Assessment for the Waste Isolation Pilot Plant, December 1992-Volume 2: Technical Basis. SAND92-0700/2. Albuquerque, NM: Sandia National Laboratories.

26. Sandia WIPP Project. 1992. Preliminary Performance Assessment for the Waste Isolation Pilot Plant, December 1992-Volume 3: Model Parameters. SAND92-0700/3. Albuquerque, NM: Sandia National Laboratories.

27. WIPP PA (Performance Assessment) Department. 1993. Preliminary Performance Assessment for the Waste Isolation Pilot Plant, December 1992-Volume 4: Uncertainty and Sensitivity Analyses for 40 CFR 191, Subpart B. SAND92-0700/4. Albuquerque, NM: Sandia National Laboratories.

28. WIPP PA (Performance Assessment) Department. 1993. Preliminary Performance Assessment for the Waste Isolation Pilot Plant, December 1992-Volume 5: Uncertainty and Sensitivity Analysis of Gas and Brine Migration for Undisturbed Performance. SAND92-0700/5. Albuquerque, NM: Sandia National Laboratories.

29. Hammersley, J.M., and D.C. Handscomb. 1964. Monte Carlo Methods. New York, NY: Chapman and Hall.

30. McKay, M.D., W.J. Conover, and R.J. Beckman. 1979. "A Comparison of Three Methods for Selecting Values of Input Variables in the Analysis of Output from a Computer Code." Technometrics 21: 239-245.

31. Iman, R. L., and M. J. Shortencarier. 1984. A FORTRAN 77 Program and User's Guide for the Generation of Latin Hypercube and Random Samples for Use With Computer Models. NUREG/CR-3624, SAND832365. Albuquerque, NM: Sandia National Laboratories. 
32. Cox, D.R., and P.A.W. Lewis. 1966. The Statistical Analysis of Series of Events. Chapman and Hall, London.

33. Haight, F.A. 1967. Handbook of the Poisson Distribution. New York, NY: John Wiley and Sons.

34. Cox, D.R., and V. Isham. 1980. Point Processes. London: Chapman and Hall.

35. Helton, J.C. 1993. "Drilling Intrusion Probabilities for Use in Performance Assessment for Radioactive Waste Disposal." Reliability Engineering and System Safety 40: 259-275.

36. Helton, J.C., and H.J. Iuzzolino. 1993. "Construction of Complementary Cumulative Distribution Functions for Comparison with the EPA Release Limits for Radioactive Waste Disposal." Reliability Engineering and System Safety 40: 277-293.

37. Helton, J.C., J.W. Garner, M.G. Marietta, R.P. Rechard, D.K. Rudeen, and P.N. Swift. 1993. "Uncertainty and Sensitivity Analysis Results Obtained in a Preliminary Performance Assessment for the Waste Isolation Pilot Plant." Nuclear Science and Engineering 114: 286-331.

38. Helton, J.C., D.R. Anderson, B.L. Baker, J.E. Bean, J.W. Berglund, W. Beyeler, J.W. Garner, H.J. Iuzzolino, M.G. Marietta, R.P. Rechard, P.J. Roache, D.K. Rudeen, J.D. Schreiber, P.N. Swift, M.S. Tierney, and P. Vaughn. In Review. "Effect of Alternative Conceptual Models in a Preliminary Performance Assessment for the Waste Isolation Pilot Plant." Nuclear Engineering and Design. (Copy on file at the Nuclear Waste Management Library, Sandia National Laboratories, Albuquerque, NM.)

39. Berglund, J.W. 1992. Mechanisms Governing the Direct Removal of Wastes from the Waste Isolation Pilot Plant Repository Caused by Exploratory Drilling. SAND92-7295. Albuquerque, NM: Sandia National Laboratories.

40. Roache, P.J. 1993. "The SECO Suite of Codes for Site Performance Assessment." High Level Radioactive Waste Management, Proceedings of the Fourth Annual International Conference, Las Vegas, NV, April 2630, 1993. Vol. 2, 1586-1594. La Grange park, IL: American Nuclear Society, Inc.

41. Huyakorn, P. S., H. O. White, Jr., and S. Panday. 1991. STAFF2D Solute Transport and Fracture Flow in 2Dimensions. Herndon, VA: HydroGeoLogic, Inc.

42. Iman, R. L., and W. J. Conover. 1982. "A Distribution-Free Approach to Inducing Rank Correlation Among Input Variables." Communications in Statistics B11: 311-334.

43. Helton, J. C. 1993. "Uncertainty and Sensitivity Analysis Techniques for Use in Performance Assessment for Radioactive Waste Disposal." Reliability Engineering and System Safety 42: 327-367.

44. Iman, R.L., and J.C. Helton. 1988. "An Investigation of Uncertainty and Sensitivity Analysis Techniques for Computer Models." Risk Analysis 8: 71-90.

45. Iman, R. L., and J. C. Helton. 1991. "The Repeatability of Uncertainty and Sensitivity Analyses for Complex Probabilistic Risk Assessments." Risk Analysis 11: 591-606.

46. Helton, J. C., J. D. Johnson, M. D. McKay, A. W. Shiver, and J. L. Sprung. In Press. "Robustness of an Uncertainty and Sensitivity Analysis of Early Exposure Results with the MACCS Reactor Accident Consequence Model." Reliability Engineering and System Safety. (Copy on file at the Nuclear Waste Management Library, Sandia National Laboratories, Albuquerque, NM.)

47. Conover, W.J. 1980. Practical Nonparametric Statistics. New York, NY: Wiley. 
(Send Distribution list changes to F. Puffer, Tech Reps. Inc., 5000 Marble NE, Suite 200 Albuquerque, NM 87110)

\section{Federal Agencies}

US Department of Energy (6)

Office of Civilian Radioactive Waste Management

Attn: Deputy Director, RW-2

Associate Director, RW-10/50

Office of Program and Resources

Management

Office of Contract Business

Management

Director, RW-22, Analysis and

Verification Division

Associate Director, RW-30

Office of Systems and Compliance

Associate Director, RW-40

Office of Storage and

Transportation

Director, RW-4/5

Office of Strategic Planning and International Programs Office of

External Relations

Forrestal Building

Washington, DC 20585

US Department of Energy

Albuquerque Operations Office

Attn: National Atomic Museum Library

PO Box 5400

Albuquerque, NM 87185

US Department of Energy (2)

Office of Environmental Restoration and

Waste Management

Attn: Director, EM-1

C. Frank, EM-50

Washington, DC 20585

US Department of Energy (3)

Office of Environmental Restoration and

Waste Management

Attn: M. Frei, EM-34 / Trevion II

Director, Waste Management Projects

Washington, DC 20585-0002
US Department of Energy

Office of Environmental Restoration and Waste Management

Attn: J. Lytle, EM-30 / Trevion II

Washington, DC 20585-0002

US Department of Energy

Office of Environmental Restoration

and Waste Management

Attn: S. Schneider, EM-342

Trevion II

Washington, DC 20585-0002

US Department of Energy (3)

WIPP Task Force

Attn: G.H. Daly

S. Fucigna

B. Bower

12800 Middlebrook Rd., Suite 400

Germantown, MD 20874

US Department of Energy (4)

Office of Environment, Safety and Health

Attn: R.P. Berube, EH-20

C. Borgstrom, EH-25

R. Pelletier, EH-231

K. Taimi, EH-232

Washington, DC 20585

US Department of Energy (6)

WIPP Project Integration Office

Attn: S. Alcorn

W.J. Arthur III

J. Coffey

L.W. Gage

P.J. Higgins

D.A. Olona

PO Box 5400

Albuquerque, NM 87115-5400 
US Department of Energy (2)

WIPP Project Integration Satellite Office

Attn: R. Batra

R. Becker

PO Box 3090, Mail Stop 525

Carlsbad, NM 88221-3090

US Department of Energy (10)

Carlsbad Operations Center Attn: A. Hunt (4)
V. Daub (4)
L. Lippis
K. Hunter

PO Box 3090

Carlsbad, NM 88221-3090

US Department of Energy

Research \& Waste Management Division

Attn: Director

PO Box E

Oak Ridge, TN 37831

US Department of Energy (2)

Idaho Operations Office

Fuel Processing and Waste Management

Division

785 DOE Place

Idaho Falls, ID 83402

US Department of Energy

Savannah River Operations Office

Defense Waste Processing

Facility Project Office

Attn: W.D. Pearson

PO Box A

Aiken, SC 29802

US Department of Energy (2)

Richland Operations Office

Waste Management Division

Attn: Rudy F. Guercia

825 Jadwin Avenue

PO Box 550

Richland, WA 99352
US Department of Energy

Office of Geologic Disposal

Yucca Mountain Project Office

Attn: Associate Director, RW-20

PO Box 98608

Las Vegas, NV 89193-8608

US Department of Energy (3)

Nevada Operations Office

Attn: J.R. Boland

D. Livingston

P.K. Fitzsimmons

2753 S. Highland Drive

Las Vegas, NV 89183-8518

US Department of Energy (2)

Technical Information Center

PO Box 62

Oak Ridge, TN 37831

US Department of Energy (2)

Chicago Operations Office

Attn: J.C. Haugen

9800 South Cass Avenue

Argonne, IL 60439

US Department of Energy (3)

Rocky Flats Area Office

Attn: W.C. Rask

G. Huffman

T. Lukow

PO Box 928

Golden, CO 80402-0928

US Department of Energy

Los Alamos Area Office

528 35th Street

Los Alamos, NM 87544

US Department of Energy

Dayton Area Office

Attn: R. Grandfield

PO Box 66

Miamisburg, $\mathrm{OH}$ 45343-0066 
US Bureau of Land Management Carlsbad Office

101 E. Mermod

Carlsbad, NM 88220

US Bureau of Land Management New Mexico State Office

PO Box 1449

Santa Fe, NM 87507

US Environmental Protection

Agency (2)

Radiation Protection Programs

Attn: M. Oge

ANR-460

Washington, DC 20460

US Environmental Protection

Agency, Region 6

tn: C. Byrum, 6T-ET

1445 Ross Ave.

Dallas, TX 75202

US Geological Survey (2)

Water Resources Division

Attn: C. Peters

4501 Indian School NE

Suite 200

Albuquerque, NM 87110

US Nuclear Regulatory Commission

Division of Waste Management

Attn: H. Marson

Mail Stop 4-H-3

Washington, DC 20555

US Nuclear Regulatory Commission (4)

Advisory Committee on Nuclear Waste

Attn: D. Moeller

M.J. Steindler

P.W. Pomeroy

W.J. Hinze

7920 Norfolk Ave.

Bethesda, MD 20814
Defense Nuclear Facilities Safety Board

Attn: D. Winters

625 Indiana Ave. NW

Suite 700

Washington, DC 20004

Nuclear Waste Technical Review Board

Attn: Library (2)

1100 Wilson Blvd.

Suite 910

Arlington, VA 22209-2297

\section{State Agencies}

New Mexico Bureau of Mines and Mineral Resources

Socorro, NM 87801

New Mexico Energy, Minerals and

Natural Resources Department

Attn: Librarian

2040 South Pacheco

Santa Fe, NM 87505

New Mexico Energy, Minerals and

Natural Resources Department

New Mexico Radioactive Task Force (2)

(Governor's WIPP Task Force)

Attn: A. Lockwood, Chairman

C. Wentz, Policy Analyst

2040 South Pacheco

Santa Fe, NM 87505

Bob Forrest

Mayor, City of Carlsbad

PO Box 1569

Carlsbad, NM 88221

Carlsbad Department of Development Executive Director

Attn: C. Bernard

PO Box 1090

Carlsbad, NM 88221 
New Mexico Environment Department

Secretary of the Environment (3)

Attn: J. Espinosa

PO Box 968

1190 St. Francis Drive

Santa Fe, NM 87503-0968

New Mexico Environment Department

Attn: P. McCasland

WIPP Project Site Office

PO Box 3090

Carlsbad, NM 88221-3090

New Mexico State Engineer's Office

Attn: M. Chudnoff

PO Box 25102

Santa Fe, NM 87504-5102

Environmental Evaluation Group (5)

Attn: R. Neill

7007 Wyoming Blvd. NE, Suite F-2

Albuquerque, NM 87109

\section{Advisory Committee on Nuclear Facility Safety}

John F. Ahearne

Executive Director, Sigma Xi

99 Alexander Drive

Research Triangle Park, NC 27709

James E. Martin

109 Observatory Road

Ann Arbor, MI 48109

WIPP Committee, National Research

Council's Board on Radioactive Waste Management

National Research Council (2)

Board on Radioactive Waste Management

Attn: C.A. Anderson

I.B. Alterman

2101 Constitution Ave. NW

Harris Bldg. HA 456

Washington, DC 20418
Howard Adler

Oxyrase, Inc.

11020 Solway School Rd.

Knoxville, TN 37931

John O. Blomeke

3833 Sandy Shore Drive

Lenoir City, TN 37771-9803

John D. Bredehoeft

Western Region Hydrologist

Water Resources Division

US Geological Survey (M/S 439)

345 Middlefield Road

Menlo Park, CA 94025

Fred M. Ernsberger

1325 NW Tenth Ave.

Gainsville, FL 32605

Rodney C. Ewing

Department of Geology

University of New Mexico

Albuquerque, NM 87131

Charles Fairhurst

Department of Civil and Mineral

Engineering

University of Minnesota

500 Pillsbury Dr. SE

Minneapolis, MN 55455-0220

B. John Garrick

PLG, Incorporated

4590 MacArthur Blvd., Suite 400

Newport Beach, CA 92660-2027

Leonard F. Konikow

US Geological Survey

431 National Center

Reston, VA 22092

Jeremiah O'Driscoll

Jody, Incorporated

505 Valley Hill Drive

Atlanta, GA 30350 
Christopher G. Whipple

ICF Kaiser Engineers

1800 Harrison St. 7th Floor

Oakland, CA 94612-3430

Thomas A. Zordan

Zordan Associates, Inc.

3807 Edinburg Dr.

Murrysville, PA 15668

Performance Assessment Peer Review Panel

G. Ross Heath

College of Ocean \& Fishery Sciences

University of Washington

583 Henderson Hall, $\mathrm{HN}-15$

Seattle, WA 98195

Thomas H. Pigford

University of California

166 Alpine Terrace

Oakland, CA 94618

Thomas A. Cotton

JK Research Associates, Inc.

4429 Butterworth Place NW

Washington, DC 20016

Robert J. Budnitz

President, Future Resources Associates, Inc.

2039 Shattuck Ave

Suite 402

Berkeley, CA 94704

C. John Mann

Department of Geology

245 Natural History Bldg.

1301 West Green Street

University of Illinois

Urbana, IL 61801
Frank W. Schwartz

Department of Geology and Mineralogy

The Ohio State University

Scott Hall

1090 Carmack Rd.

Columbus, OH 43210

\section{National Laboratories}

Argonne National Laboratory (2)

Attn: A. Smith

D. Tomasko

9700 South Cass, Bldg. 201

Argonne, IL 60439

Battelle Pacific Northwest

Laboratory (2)

Attn: S. Bates

R.E. Westerman

MSIN P8-44

Battelle Boulevard

Richland, WA 99352

Idaho National Laboratory (2)

Westinghouse-Idaho Nuclear Co.

Attn: H. Loo

R. Klingler

Mail Stop 3422

P.O. Box 4000

Idaho Falls, ID 83415-3422

Los Alamos National Laboratory (5)

Attn: B. Erdal, INC-12

M. Ennis, HS-12

Mail Stop J900

S. Kosiewicz, EM-7

Mail Stop J595

L. Soholt, EM-13

Mail Stop M992

J. Wenzel, HS-12

Mail Stop K482

PO Box 1663

Los Alamos, NM 87545 
Oak Ridge National Laboratory

Transuranic Waste Manager

Attn: D.W. Turner

Bldg. 3047

PO Box 2008

Oak Ridge, TN 37831-6060

Pacific Northwest Laboratory

Attn: B. Kennedy

PO Box 999

Richland, WA 99352

Westinghouse--Savannah River

Technology

Center (4)

Attn: N. Bibler

J.R. Harbour

M.J. Plodinec

G.G. Wicks

Aiken, SC 29802

\section{Corporations/Members of the Public}

Battelle Memorial Institute

Attn: R. Root

J. Kircher

505 Marquette NW, Suite 1

Albuquerque, NM 87102

Benchmark Environmental Corp.

Attn: C. Frederickson

4501 Indian School NE, Suite 105

Albuquerque, NM 87110

Beta Corporation Int.

Attn: E. Bonano

6613 Esther NE

Albuquerque, NM 87109

City of Albuquerque

Public Works Department

Utility Planning Division

Attn: W.K. Summers

PO Box 1293

Albuquerque, NM 87103
Deuel and Associates, Inc.

Attn: R.W. Prindle

7208 Jefferson NE

Albuquerque, NM 87109

Disposal Safety, Inc.

Attn: B. Ross

1660 L Street NW, Suite 314

Washington, DC 20036

Ecodynamics (2)

Attn: P. Roache

R. Blaine

PO Box 9229

Albuquerque, NM 87119-9229

EG \& G Idaho (3)

1955 Fremont Street

Attn: C. Atwood

C. Hertzler

T.I. Clements

Idaho Falls, ID 83415

Geomatrix

Attn: K. Coppersmith

100 Pine St., Suite 1000

San Francisco, CA 94111

Golder Associates, Inc.

Attn: R. Kossik

4104 148th Avenue NE

Redmond, WA 98052

John Hart and Associates, P.A.

Attn: J.S. Hart

2815 Candelaria Road NW

Albuquerque, NM 87107

John Hart and Associates, P.A.

Attn: K. Lickliter

400-C 8th St. NW

Tacoma, WA 98439

INTERA, Inc.

Attn: A.M. LaVenue

1650 University Blvd. NE, Suite 300

Albuquerque, NM 87102 
INTERA, Inc.

Attn: J.F. Pickens

6850 Austin Center Blvd., Suite 300

Austin, TX 78731

INTERA, Inc.

Attn: W. Stensrud

PO Box 2123

Carlsbad, NM 88221

INTERA, Inc.

Attn: W. Nelson

101 Convention Center Dr.

Suite 540

Las Vegas, NV 89109

IT Corporation (2)

Attn: R.F. McKinney

$$
\text { J. Myers }
$$

Regional Office, Suite 700

5301 Central Avenue NE

Albuquerque, NM 87108

Lawrence Berkeley Laboratory

Attn: J. Long

Building $50 \mathrm{E}$

Berkeley, CA 94720

Newman and Holtzinger

Attn: C. Mallon

1615 L Street NW, Suite 1000

Washington, DC 20036

RE/SPEC, Inc. (2)

Attn: W. Coons

4775 Indian School NE, Suite 300

Albuquerque, NM 87110

RE/SPEC, Inc.

Attn: J.L. Ratigan

PO Box 725

Rapid City, SD 57709
Reynolds Electric and Engineering

Company, Inc.

Attn: E.W. Kendall

Building 790

Warehouse Row

PO Box 98521

Las Vegas, NV 89193-8521

SAIC

Attn: H.R. Pratt

10260 Campus Point Drive

San Diego, CA 92121

SAIC

Attn: C.G. Pflum

101 Convention Center Dr.

Las Vegas, NV 89109

SAIC (3)

Attn: M. Davis

R. Guzowski

J. Tollison

2109 Air Park Road SE

Albuquerque, NM 87106

SAIC (2)

Attn: J. Young

D. Lester

18706 North Creek Parkway, Suite 110

Bothell, WA 98011

Southwest Research Institute

Nuclear Waste Regulatory Analysis (2)

Attn: P.K. Nair

6220 Culebra Road

San Antonio, TX 78228-0510

Systems, Science, and Software (2)

Attn: E. Peterson

$$
\text { P. Lagus }
$$

Box 1620

La Jolla, CA 92038

TASC

Attn: S.G. Oston

55 Walkers Brook Drive

Reading, MA 01867 
Tech Reps, Inc. (6)

Attn: J. Chapman

C. Crawford

D. Marchand

T. Peterson

J. Stikar

D. Scott

5000 Marble NE, Suite 222

Albuquerque, NM 87110

Tolan, Beeson \& Associates

Attn: T.L. Tolan

2320 W. 15th Avenue

Kennewick, WA 99337

TRW Environmental Safety Systems (2)

Attn: I. Sacks, Suite 800

L. Wildman, Suite 1300

2650 Park Tower Drive

Vienna, VA 22180-7306

Sanford Cohen and Associates

Attn: J. Channell

7101 Carriage Rd NE

Albuquerque, NM 87109

Westinghouse Electric Corporation (5)

Attn: Library

C. Cox

L. Fitch

B.A. Howard

R.F. Kehrman

PO Box 2078

Carlsbad, NM 88221

Westinghouse Hanford Company

Attn: D.E. Wood, MSIN HO-32

PO Box 1970

Richland, WA 99352

Western Water Consultants

Attn: P.A. Rechard

PO Box 4128

Laramie, WY 82071
Western Water Consultants

Attn: D. Fritz

1949 Sugarland Drive \#134

Sheridan, WY 82801-5720

WTECH

Attn: Carl Hess

101 E. Mermod

Carlsbad, NM 88220

P. Drez

8816 Cherry Hills Road NE

Albuquerque, NM 87111

David Lechel

9600 Allende Rd. NE

Albuquerque, NM 87109

C.A. Marchese

PO Box 21790

Albuquerque, NM 87154

Arend Meijer

3821 Anderson SE

Albuquerque, NM 87108

D.W. Powers

Star Route Box 87

Anthony, TX 79821

Shirley Thieda

PO Box 2109, RR1

Bernalillo, NM 87004

Jack Urich

c/o CARD

144 Harvard SE

Albuquerque, NM 87106

\section{Universities}

University of California

Mechanical, Aerospace, and

Nuclear Engineering Department (2)

Attn: W. Kastenberg

D. Browne

5532 Boelter Hall

Los Angeles, CA 90024 


\section{Libraries}

University of California

Engineering and Applied Science

Attn: D. Okrent

48-121A Engineering IV

Los Angeles, CA 90024-1597

University of California

Mine Engineering Department

Rock Mechanics Engineering

Attn: N. Cook

Berkeley, CA 94720

University of Hawaii at Hilo

Business Administration

Attn: S. Hora

Hilo, HI 96720-4091

University of Illinois

Department of Geology

Attn: C. Bethke

1301 W. Green St.

Urbana, IL 61801

University of New Mexico

Geology Department

Attn: Library

Albuquerque, NM 87131

University of New Mexico

Research Administration

Attn: H. Schreyer

102 Scholes Hall

Albuquerque, NM 87131

University of Wyoming

Department of Civil Engineering

Attn: V.R. Hasfurther

Laramie, WY 82071

University of Wyoming

Department of Geology

Attn: J.I. Drever

Laramie, WY 82071
Thomas Brannigan Library

Attn: D. Dresp

106 W. Hadley St.

Las Cruces, NM 88001

New Mexico State Library

Attn: N. McCallan

325 Don Gaspar

Santa Fe, NM 87503

New Mexico Tech

Martin Speere Memorial Library

Campus Street

Socorro, NM 87810

New Mexico Junior College

Pannell Library

Attn: R. Hill

Lovington Highway

Hobbs, NM 88240

Carlsbad Municipal Library

WIPP Public Reading Room

Attn: L. Hubbard

101 S. Halagueno St.

Carlsbad, NM 88220

University of New Mexico

Zimmerman Library

Government Publications Department

Albuquerque, NM 87131

\section{NEA/Performance Assessment Advisory Group (PAAG)}

P. Duerden

ANSTO

Lucas Heights Research Laboratories

Private Mail Bag No. 1

Menai, NSW 2234

AUSTRALIA 
Gordon S. Linsley

Division of Nuclear Fuel Cycle and Waste

Management

International Atomic Energy Agency

PO Box 100

A-1400 Vienna, AUSTRIA

Nicolo Cadelli

Commission of European Communities 200, Rue de la Loi

B-1049 Brussels, BELGIUM

R. Heremans

Organisme Nationale des Déchets

Radioactifs et des Matiéres Fissiles

(ONDRAF)

Place Madou 1, Boitec 24/25

B-1030 Brussels, BELGIUM

J. Marivoet

Centre d'Etudes de l'Energie Nucléaire

(CEN/SCK)

Boeretang 200

B-2400 Mol, BELGIUM

P. Conlon

Waste Management Division

Atomic Energy Control Board (AECB)

PO Box 1046

Ottawa, Ontario KIP 559, CANADA

A.G. Wikjord

Manager, Environmental and Safety

Assessment Branch, AECL

Whiteshell Laboratories

Pinawa, Manitoba ROE 1LO, CANADA

Teollisuuden Voima Oy (TVO) (2)

Attn: Timo Äikäs

Jukka-Pekka Salo

Annankatu $42 \mathrm{C}$

SF-00100 Helsinki Suomi, FINLAND
Timo Vieno

Technical Research Centre of Finland

(VTT)

Nuclear Energy Laboratory

PO Box 208

SF-02151 Espoo, FINLAND

Division de la Sécurité et de la Protection de l'Environment (DSPE)

Commissariat á l'Energie Atomique

Agence Nationale pour la Gestion des

Déchets Radioactifs (ANDRA)

Attn: Gérald Ouzounian

M. Claude Ringeard

Route du Panorama Robert Schuman

B. P. No. 38

F-92266 Fontenay-aux-Roses Cedex

FRANCE

Claudio Pescatore

Division of Radiation Protection and

Waste Management

OECD Nuclear Energy Agency

38, Boulevard Suchet

F-75016 Paris, FRANCE

M. Dominique Greneche

Commissariat á 1'Energie Atomique

IPSN/DAS/SASICC/SAED

B.P. No. 6

F-92265 Fontenay-aux-Roses Cedex

FRANCE

Robert Fabriol

Bureau de Recherches Géologiques et

Miniéres (BRGM)

B.P. 6009

45060 Orléans Cedex 2

FRANCE

P. Bogorinski

Gesellschaft für Reaktorsicherheit (GRS)

MBH

Schwertnergasse 1

D-5000 Köln 1, GERMANY 
R. Storck

GSF - Institut für Tieflagerung

Theodor-Heuss-Strabe 4

D-3300 Braunschweig, GERMANY

Ferrucio Gera

ISMES S.p.A

Via del Crociferi 44

I-00187 Rome, ITALY

Hiroyuki Umeki

Isolation System Research Program

Radioactive Waste Management Project

Power Reactor and Nuclear Fuel

Development Corporation (PNC)

1-9-13, Akasaka, Minato-ku

Tokyo 107, JAPAN

Tönis Papp

Swedish Nuclear Fuel and Waste

Management Co.

Box 5864

S 10248 Stockholm

SWEDEN

Conny Hägg

Swedish Radiation Protection Institute

(SSI)

Box 60204

S-104 01 Stockholm, SWEDEN

J. Hadermann

Paul Scherrer Institute

Waste Management Programme

CH-5232 Villigen PSI

SWITZERLAND

J. Vigfusson

HSK-Swiss Nuclear Safety Inspectorate

Federal Office of Energy

CH-5232 Villigen-HSK

SWITZERLAND
D.E. Billington

Departmental Manager-Assessment

Studies

Radwaste Disposal R\&D Division

AEA Decommissioning \& Radwaste

Harwell Laboratory, B60

Didcot Oxfordshire OX11 ORA

UNITED KINGDOM

P. Grimwood

Waste Management Unit, BNFL

Sellafield

Seascale, Cumbria CA20 1PG

UNITED KINGDOM

Alan J. Hooper

UK Nirex Ltd

Curie Avenue

Harwell, Didcot

Oxfordshire, OX11 ORH

UNITED KINGDOM

Jerry M. Boak

Yucca Mountain Project Office

US Department of Energy

PO Box 98608

Las Vegas, NV 89193

Seth M. Coplan (Chairman)

US Nuciear Regulatory Commission

Division of HLW Management

Mail Stop 4-H-3

Washington, DC 20555

A.E. Van Luik

INTERA/M\&O

The Valley Bank Center

101 Convention Center Dr.

Las Vegas, NV 89109 
NEA/Probabilistic System Assessment Group (PSAG)

Shaheed Hossain

Division of Nuclear Fuel Cycle and

Waste Management

International Atomic Energy Agency

Wagramerstrasse 5

PO Box 100

A-1400 Vienna, AUSTRIA

Eduard Hofer

Gesellschaft für Reaktorsicherheit (GRS)

$\mathrm{MBH}$

Forschungsgelände

D-8046 Garching, GERMANY

Andrea Saltelli

Commission of European Communities

Joint Resarch Centre of Ispra

I-21020 Ispra (Varese), ITALY

Alejandro Alonso

Cátedra de Tecnología Nuclear

E.T.S. de Ingenieros Industriales

José Gutiérrez Abascal, 2

E-28006 Madrid, SPAIN

ENRESA (2)

Attn: M. A. Cuñado

F. J. Elorza

Calle Emilio Vargas, 7

E-28043 Madrid, SPAIN

Pedro Prado

CIEMAT

Instituto de Tecnología Nuclear

Avenida Complutense, 22

E-28040 Madrid, SPAIN

Nils A. Kjellbert

Swedish Nuclear Fuel and Waste

Management

Company (SKB)

Box 5864

S-102 48 Stockholm, SWEDEN
Björn Cronhjort

Royal Institute of Technology

Automatic Control

S-100 44 Stockholm, SWEDEN

Richard A. Klos

Paul-Scherrer Institute (PSI)

CH-5232 Villingen PSI, SWITZERLAND

Nationale Genossenschaft für die

Lagerung Radioaktiver Abfälle (2)

Attn: C. McCombie

F. Van Dorp

Hardstrasse 73

CH-5430 Wettingen, SWITZERLAND

N. A. Chapman

Intera Information Technologies

Park View House, 14B Burton Street

Melton Mowbray

Leicestershire LE13 1AE

UNITED KINGDOM

Daniel A. Galson

Galson Sciences Ltd.

5 Grosvenor House

Melton Road

Oakham

Rutland LE15 6AX

UNITED KINGDOM

David P. Hodgkinson

Intera Information Technologies

45 Station Road, Chiltern House

Henley-on-Thames

Oxfordshire RG9 1AT

UNITED KINGDOM

Brian G.J. Thompson

Department of the Environment: Her

Majesty's Inspectorate of Pollution

Room A5.33, Romney House

43 Marsham Street

London SW1P 2PY, UNITED

KINGDOM 
Intera Information Technologies

Attn: M.J.Apted

3609 South Wadsworth Blvd.

Denver, CO 80235

US Nuclear Regulatory Commission (2)

Attn: R. Codell

$N$. Eisenberg

Mail Stop 4-H-3

Washington, DC 20555

Battelle Pacific Northwest Laboratories

Attn: P.W. Eslinger

MS K2-32

PO Box 999

Richland, WA 99352

Center for Nuclear Waste Regulatory

Analysis (CNWRA)

Southwest Research Institute

Attn: B. Sagar

PO Drawer 28510

6220 Culebra Road

San Antonio, TX 78284

\section{Geostatistics Expert Working Group} (GXG)

Rafael L. Bras

R.L. Bras Consulting Engineers

44 Percy Road

Lexington, MA 02173

Jesus Carrera

Universidad Politècnica de Cataluña

E.T.S.I. Caminos

Jordi, Girona 31

E-08034 Barcelona, SPAIN

Gedeon Dagan

Department of Fluid Mechanics and Heat

Transfer

Tel Aviv University

PO Box 39040

Ramat Aviv, Tel Aviv 69978

ISRAEL
Ghislain de Marsily (GXG Chairman)

University Pierre et Marie Curie

Laboratorie de Geologie Applique

4 , Place Jussieu

T.26 - $5^{\mathrm{e}}$ etage

75252 Paris Cedex 05

FRANCE

Alain Galli

Centre de Geostatistique

Ecole des Mines de Paris

35 Rue St. Honore

77035 Fontainebleau, FRANCE

Christian Ravenne

Geology and Geochemistry Division

Institut Francais du Pétrole

$1 \&$ 4, Av. de Bois-Préau B.P. 311

92506 Rueil Malmaison Cedex

FRANCE

Peter Grindrod

INTERA Information Technologies Ltd.

Chiltern House

45 Station Road

Henley-on-Thames

Oxfordshire, RG9 1AT, UNITED

KINGDOM

Alan Gutjahr

Department of Mathematics

NM Institute of Mining and Technology

Socorro, NM 87801

C. Peter Jackson

Harwell Laboratory

Theoretical Studies Department

Radwaste Disposal Division

Bldg. 424.4

Oxfordshire Didcot Oxon OX11 ORA

UNITED KINDGOM

Rae Mackay

Department of Civil Engineering

University of Newcastle Upon Tyne

Newcastle Upon Tyne NE1 7RU

UNITED KINGDOM 
Steve Gorelick

Department of Applied Earth Sciences

Stanford University

Stanford, CA 94305-2225

Peter Kitanidis

60 Peter Coutts Circle

Stanford, CA 94305

Dennis McLaughlin

Parsons Laboratory

Room 48-209

Department of Civil Engineering

Massachusetts Institute of Technology

Cambridge, MA 02139

Shlomo P. Neuman

College of Engineering and Mines

Hydrology and Water Resources Dept.

University of Arizona

Tucson, AZ 85721

Yoram Rubin

Department of Civil Engineering

University of California

Berkeley, CA 94720

\section{Foreign Addresses}

Studiecentrum Voor Kernenergie

Centre D'Energie Nucleaire

Attn: A. Bonne

SCK/CEN

Boeretang 200

B-2400 Mol, BELGIUM

Atomic Energy of Canada, Ltd. (3)

Whiteshell Laboratories

Attn: M.E. Stevens

B.W. Goodwin

D. Wushke

Pinewa, Manitoba ROE 1L0, CANADA

Juhani Vira

Teollisuuden Voima Oy (TVO)

Annankatu $42 \mathrm{C}$

SF-00100 Helsinki Suomi

FINLAND
Jean-Pierre Olivier

OECD Nuclear Energy Agency (2)

38, Boulevard Suchet

F-75016 Paris, FRANCE

D. Alexandre, Deputy Director

ANDRA

31 Rue de la Federation

75015 Paris, FRANCE

Claude Sombret

Centre D'Etudes Nucleaires

De La Vallee Rhone

CEN/VALRHO

S.D.H.A. B.P. 171

30205 Bagnols-Sur-Ceze, FRANCE

Commissariat a L'Energie Atomique

Attn: D. Alexandre

Centre d'Études de Cadarache

13108 Saint Paul Lez Durance Cedex

FRANCE

Bundesministerium für Forschung und Technologie

Postfach 200706

5300 Bonn 2, GERMANY

Bundesanstalt für Geowissenschaften und Rohstoffe

Attn: M. Langer

Postfach 510153

D-30631 Hannover, GERMANY

Gesellschaft für Anlagen und

Reaktorsicherheit (GRS)

Attn: B. Baltes

W. Muller

Schwertnergasse 1

D-50667 Cologne, GERMANY

Institut fur Tieflagerung (2)

Attn: K. Kuhn

Theodor-Heuss-Strasse 4

D-3300 Braunschweig

GERMANY 
Physikalisch-Technische

Bundesanstalt

Attn: P. Brenneke

Postfach 3345

D-3300 Braunschweig

GERMANY

Shingo Tashiro

Japan Atomic Energy Research Institute

Tokai-Mura, Ibaraki-Ken

319-11, JAPAN

Netherlands Energy Research Foundation (ECN)

Attn: L.H. Vons

3 Westerduinweg

PO Box 1

1755 ZG Petten

THE NETHERLANDS

Johan Andersson

Swedish Nuclear Power Inspectorate

Statens Kärnkraftinspektion (SKI)

Box 27106

S-102 52 Stockholm

SWEDEN

Fred Karlsson

Svensk Kärnbränsleforsorjning $\mathrm{AB}$

Project KBS

Box 5864

S-102 48 Stockholm

SWEDEN

Nationale Genossenschaft für die

Lagerung Radioaktiver Abfälle (2)

Attn: S. Vomvoris

P. Zuidema

Hardstrasse 73

CH-5430 Wettingen

SWITZERLAND

AEA Technology

Attn: J.E. Tinson

B4244 Harwell Laboratory

Didcot, Oxfordshire OX11 ORA

UNITED KINGDOM
AEA Technology

Attn: J.H. Rees

D5W/29 Culham Laboratory

Abington

Oxfordshire OX14 3DB

UNITED KINGDOM

AEA Technology

Attn: W.R. Rodwell

O44/A31 Winfrith Technical Centre

Dorchester

Dorset DT2 8DH, UNITED KINGDOM

D.R. Knowles

British Nuclear Fuels, plc

Risley, Warrington

Cheshire WA3 6AS, 1002607

UNITED KINGDOM

\section{Internal}

MS Org.

01010001

01020002

08271502

08271511

01274511

07246000

13246115

13246115

07506118

13206119

13206119

13226121

13226121

13376300

13356302

13956700

13356303

13356305

13456307

13416306

13266312

13266313

13456331

13306352

13286342

13286342
A. Narath
O.E. Jones
P.J. Hommert
D.K. Gartling
D.P. Garber
D.L. Hartley
P.B. Davies
R.L. Beauheim
H.R. Westrich
E.J. Nowak
Staff (14)
J.R. Tillerson
Staff (7)
D.E. Ellis
L.E. Shephard
S.Y. Pickering
W.D. Weart
S.A. Goldstein
A.R. Lappin
A.L. Stevens
F.W. Bingham
L.S. Costin
P.A. Davis
WIPP Central Files (20)
D.R. Anderson
Staff (20) 
13956743 V.H. Slaboszewicz

13956743 Staff (3)

13416345 R.C. Lincoln

13416345 Staff (9)

13416347 D.R. Schafer

13416348 J.T. Holmes

$13416348 \quad$ Staff (4)

13436351 R.E. Thompson

13306352 G. Gerstner-Miller (2)

$07366400 \quad$ N.R. Ortiz

$07466613 \quad$ R.M. Cranwell

07466613 R.L. Iman

07466613 C. Leigh

07276622 M.S.Y. Chu

$07186641 \quad$ R.E. Luna, Acting

089913414 Technical Library (5)

061913416 Technical Publications

0100 7613-2 Document Processing for DOE/OSTI (10)

9018 8523-2 Central Technical Files 